Espinos A, Romero ML*, Hospitaler A, Pascual AM, Albero V, “Advanced materials for concrete-filled tubular columns and connections “, Structures 2015; 4: 105-113.

http://dx.doi.org/10.1016/j.istruc.2015.08.006

\title{
Advanced materials for concrete-filled tubular columns and connections
}

Ana Espinos ${ }^{\mathrm{a}}$, Manuel L. Romero ${ }^{\mathrm{a}, *}$, Antonio Hospitaler ${ }^{\mathrm{a}}$, Ana M. Pascual ${ }^{\mathrm{a}}$, Vicente Albero ${ }^{\mathrm{a}}$

${ }^{a}$ Instituto de Ciencia y Tecnología del Hormigón (ICITECH), Universitat Politècnica de València, Valencia, Spain

*Corresponding author.e-mail address: mromero@mes.upv.es

\section{ABSTRACT}

The advantages of concrete-filled steel tubular (CFST) columns are well known at room and elevated temperatures, however, beyond a certain slenderness their load-bearing capacity starts to decrease. Besides, blind-bolts represent a proper system to allow endplate bolted connections to hollow steel tubular columns and CFST, although the resistance of the bolt shank conditions affects the performance of the connection. In this paper, the use of innovative materials is proposed as a method of enhancing of the load-bearing capacity for both CFST columns and connections. In this line, a first approach of the benefits using high strength steel, fire-resistant steel and geopolymer concrete applied for CFST columns in the fire situation is developed, obtaining better fire results although depending on the columns cross-sections configuration and the part where the advanced material is applied. Related to blind-bolts connections under fire conditions, the use of fire-resistant bolts is assessed. Their higher strength retention in fire could avoid the use of protection, but only in limited cases. Furthermore, a preliminary study on shape memory alloys in the blind-bolts is performed at room temperature and supporting cyclic pull-out loading.

Keywords: Concrete-filled steel tube; Fire resistance; Advanced materials; High strength steel; Fire-resistant steel; Blind-bolts; Shape memory alloys; superelastic 
Espinos A, Romero ML*, Hospitaler A, Pascual AM, Albero V, “Advanced materials for concrete-filled tubular columns and connections “, Structures 2015; 4: 105-113. http://dx.doi.org/10.1016/j.istruc.2015.08.006

NOTATION

$\begin{array}{ll}\text { CFST } & \text { Concrete-filled steel tube } \\ \text { CHS } & \text { Circular Hollow Section } \\ \text { HSS } & \text { High Strength Steel } \\ \text { FE } & \text { Finite Element } \\ \text { FR } & \text { Fire Resistant } \\ \text { FRR } & \text { Fire Resistance rating } \\ \mathrm{f}_{\mathrm{y}} & \text { Yield strength of steel } \\ \mathrm{f}_{\mathrm{u}} & \text { Ultimate strength of steel } \\ \text { HB } & \text { Hollo-Bolt } \\ \text { SMA } & \text { Shape memory alloy } \\ \text { UHB } & \text { Unfilled Hollo-Bolt }\end{array}$

\section{INTRODUCTION}

This paper deals with innovative materials in Concrete-Filled Steel Tubular (CFST) columns and blind-bolted connections to hollow steel section columns and CFST columns. CFST columns are being increasingly used in modern buildings due to their high load-bearing capacity, elevated ductility and, in particular, their higher fire resistance as compared to traditional steel solutions. Besides, the connection between beam and tubular columns represented initially a handicap for designers due to the scarce knowledge and data, but nowadays several commercial fastener systems (including blind-bolts, able to be tightened form one side of the columns) have proved their ability to provide the required capacity.

The purpose using advanced materials is the resistance enhancement at room temperature and under fire conditions of both CFST columns and connections.

In the case of CFST columns with high slenderness, the fire performance limits their use, as already proved in previous experimental (Romero et al.[1], Moliner et al. [2]) and numerical 
Espinos A, Romero ML*, Hospitaler A, Pascual AM, Albero V, “Advanced materials for concrete-filled tubular columns and connections “, Structures 2015; 4: 105-113. http://dx.doi.org/10.1016/j.istruc.2015.08.006

(Espinos et al. [3], [4]) investigations. Two strategies can be considered to increase the fire resistance of CFST columns: On one hand the usage of innovative cross-sections like doubleskin and double-tube columns (Zhao et al. [5], [6], Han et al. [7] or Romero et al. [8]), and on the other hand the improvement of the fire resistance by using advanced materials in columns and connections. Nonetheles, in this paper the emphasis is on the materials.

Regarding blind-bolted connections between beam and tubular column, the capacity of the blind-bolt is usually determining the connection resistance. The use of new bolt materials represents a method of enhancement at room and elevated temperatures [9][10]

High strength steels (HSS) with a yield strength (fy) over $420 \mathrm{MPa}$ are acquiring an increasing popularity in the construction market, having been used in recent construction, such as the "Freedom Tower" in New York (USA), the Olympic Stadium “Bird's Nest” in Beijing (China) or the Millau viaduct (France) [11].

In structural steelwork, high strength steels allow using less material amount, which in turn reduces the costs associated to construction, transport and assembly. Regarding their behavior at elevated temperature, limited information exists in the literature and the building codes do not include design recommendations for this type of steels in the fire situation. Only results from Lange and Wohlfeil [12], Schneider and Lange [13] and Outinen [14] on HSS S460, or Chen et al. [15] and Chiew et al. [16] for HSS S690 can be found. Recently, Qiang [11], [17], [18], investigated the properties at elevated temperatures of HSS S460, S690 and S960, proposing reduction coefficients of the mechanical properties of these steels at elevated temperature based on experimental results, see Fig. 1. Tondini et al. [19] conducted three fire tests on circular hollow sections (CHS) and an additional fire test on a CFST column using HSS, where the superior performance of these steels was proved. Besides, other report from Zhao et al. [20] based on recent research works in HSS tubular members and connections can be pointed out. 
Espinos A, Romero ML*, Hospitaler A, Pascual AM, Albero V, “Advanced materials for concrete-filled tubular columns and connections “, Structures 2015; 4: 105-113. http://dx.doi.org/10.1016/j.istruc.2015.08.006

Concerning Fire Resistant (FR) steels, their recent development is motivated by the higher fire resistance requirements on the building codes. One of the ways for meeting these requirements is to use external protection (mineral wool, intumescent coating, etc.) to limit the temperature of the steel members. However, these options increase the construction costs and require a periodic maintenance. In turn, through the use of FR steels, external protection is only needed for temperatures over $600{ }^{\circ} \mathrm{C}$ [21], which allows for a significant reduction of the use of passive protection, being most of the times unnecessary. Thus, the use of FR steels reduces the construction costs and times, while it allows for a more efficient use of space.

The improvement in the mechanical properties at elevated temperatures of FR steels is due to their different chemical composition and the hot rolling process itself. According to the studies by Sakumoto et al. [22], [23], [24], while the yield strength of conventional steels starts to decrease around $350{ }^{\circ} \mathrm{C}$ (2/3 of its value at room temperature), the yield strength of FR steels remains over $2 / 3$ of its room temperature value above $600{ }^{\circ} \mathrm{C}$ (Fig. 2), which means a significant increase of strength as compared to conventional steels.

Kelly and Sha [25] confirmed that the mechanical properties of FR steels at elevated temperatures are higher than those of conventional steels, retaining a $50 \%$ of their room temperature capacity up to $650{ }^{\circ} \mathrm{C}$.

These steels have been tested by authors as Chung et al. [26] in beams forming steel connections, proving their better fire performance. Their utility in steel columns was verified through a fire test carried out in Japan [21], where it was found that the fire resistance time of a column using FR steel was higher than that of a column of the same dimensions fabricated with a conventional steel.

Fire resistant steel bolts were tested by Sakumoto et al. [27] under tensile and shear loads. Specific reduction factors were obtained which evidenced the higher strength retention capacity of this type of bolts in comparison with conventional steel Fig. 3. 
Espinos A, Romero ML*, Hospitaler A, Pascual AM, Albero V, “Advanced materials for concrete-filled tubular columns and connections “, Structures 2015; 4: 105-113. http://dx.doi.org/10.1016/j.istruc.2015.08.006

Other innovative materials are Shape Memory Alloys (SMAs) whose ability to recover their shape after suffering large deformations has found application in many fields, e. g. for medical applications, in the aerospace industry or for seismic structural design. SMAs present two unique properties: shape memory effect, that involves a recovery while through heating when the SMAs are deformed in its martensitic form; and superelastic effect, when deformation under their austenitic form is recovered removing the load. The last SMAs property makes them highly appropriate for seismic resistant design. Their recentering and energy dissipation capability have attracted the attention of researches and engineers. During the last decade the effort to increase the knowledge and application of these materials has been reflected in several investigations. For instance, DesRoches et al. [28] tested SMA wires and bars, comparing their characteristics under different sizes, loading histories and loading rates. The superelastic effect on the cyclic behaviour of beam to column connections has been also undertaken by Fang et al.[29] and Yam et al. [30] in end-plate connections, Wang et al. [31] in connections to CHS columns or Hu et al. [32] in partial restraint connections to CFST columns.

Apart from steel, the enhancement in the case of CFST columns can be achieved by a better performance of the concrete. In that respect, the use of geopolymer concrete has been considered. This type of concrete is an aluminosilicate binder, an alternative to Portland cement, which can promote the sustainability in the cement and concrete industry in terms of $\mathrm{CO}_{2}$ emissions and production energy requirement [33]. Related to its fire resistance, one of the applications is to produce a concrete with an enhanced fire resistance with lower thermal conductivity and higher strength retention at elevated temperature than normal concretes [34], [35].

The presented advantages of these types of innovative steels and concretes open a new range of possibilities regarding their application in CFST columns and connections. This paper reports on the assessment of using HSS, FR steels and geopolymer concrete in CFST columns 
Espinos A, Romero ML*, Hospitaler A, Pascual AM, Albero V, “Advanced materials for concrete-filled tubular columns and connections “, Structures 2015; 4: 105-113. http://dx.doi.org/10.1016/j.istruc.2015.08.006

in order to obtain an elevated fire resistance without the need of external protection, with the subsequent cost and time savings. In blind-bolted connections to tubular columns, the effect on the fire capacity by utilizing FR steel bolts is evaluated. In addition, the use of SMAs under cyclic loading is also studied as a first attempt to determine the benefits of using these alloys in blind-bolted connections to hollow steel and CFST columns.

\section{IMPROVEMENT OF CFST COLUMNS}

\subsection{Innovative cross-section columns}

The aim of this section is to compare the fire performance of different cross-section configurations, with similar external aspect and steel usage. For that purpose, a reference circular CFST column with dimensions $193.7 \times 8 \mathrm{~mm}$ (Fig. 4a) is compared with a double tube column (Fig. 4b) and a double skin column (Fig. 4c) of the same external dimensions and equivalent steel area. The outer steel tube of the reference CFST column is split into two tubes of equal total steel area, for obtaining the equivalent double tube and double skin columns.

The column length is $3180 \mathrm{~mm}$, with pinned-pinned end conditions and the load applied $325.4 \mathrm{kN}$, which corresponds to a $20 \%$ of the maximum capacity of the double tube column at room temperature. A steel yield strength of $355 \mathrm{MPa}$ has been used for all the steel tubes and a $30 \mathrm{MPa}$ concrete cylinder compressive strength was considered.

The behaviour of each CFST column in the fire situation under the conditions described was obtained from a validated and accurate finite element model developed by the authors [36]. This FE model provides a numerical response which is useful to compare the behaviour of the different cross-section shapes and the application of advanced materials in the next sections.

As can be seen in Fig. 5, compared to the fire resistance of the reference CFST column, of only 41 minutes, using a double skin configuration increases the fire resistance to 63 min. 
Espinos A, Romero ML*, Hospitaler A, Pascual AM, Albero V, “Advanced materials for concrete-filled tubular columns and connections “, Structures 2015; 4: 105-113. http://dx.doi.org/10.1016/j.istruc.2015.08.006

This increment is due to the fact that, in double skin configurations, when the outer tube reaches its critical temperature and has lost its load-bearing capacity, the load is transferred to the inner steel tube, whose expansion leads to an increase in axial displacement, until the final failure occurs. Besides the double tube solution provides the best fire performance with 87 min fire resistance.

This is due to the fact that filling the inner steel tube with concrete (double tube solution) delays the temperature rise within the column cross-section and therefore lengthens its fire resistance. The presence of a colder inner tube, protected by the outer concrete ring, helps resisting the second order effects in slender columns, solving the problems of CFST columns in the fire situation.

Regarding the distribution of thicknesses between the inner and outer steel tubes in the case of the double tube and double skin columns, it was proved in previous investigations [8] that using a thinner outer tube and a thicker inner tube provides the optimal fire performance (see Fig. 6), as the concrete ring protects the inner tube and therefore delays its temperature rise. It can also be seen in this figure that the configuration using normal strength concrete in both the inner core and external ring presents a higher fire resistance. The notation used in Fig. 6 was Caaa-b-cc_Cddd-e-ff, where aaa $=$ outer diameter, $\mathrm{b}=$ outer steel tube thickness, $\mathrm{cc}=$ outer concrete grade, ddd = inner diameter, e = inner steel tube thickness and ff $=$ inner concrete grade.

\subsection{Advanced materials in CFST columns}

The effect of using high performance materials, such as high strength steels (HSS), fire resistant (FR) steels and geopolymer concrete is studied in this section. Steel grades of 460, 690 and $960 \mathrm{MPa}$ are used. 
Espinos A, Romero ML*, Hospitaler A, Pascual AM, Albero V, “Advanced materials for concrete-filled tubular columns and connections “, Structures 2015; 4: 105-113. http://dx.doi.org/10.1016/j.istruc.2015.08.006

Firstly, a double tube column which provided the best fire performance in the last section was used, with an outer tube of $200 \times 3 \mathrm{~mm}$ and an inner tube of $114.3 \times 8 \mathrm{~mm}$. A first comparison was carried out at room temperature, where different combinations of HSS were used for the inner and outer tubes: 355-355, 355-460, 355-690, 355-960, 460-355, 690-355, 960-355. As expected, through Fig. 7, it can be seen that the solution which presents the higher maximum capacity at room temperature is the one where the higher steel grade is located at the outer tube (960-355), followed by 690-350 and 460-355. Therefore, at room temperature, it results more effective to place the HSS at the outer tube, while using HSS at the inner tube only increases the ductility of the columns but does not contribute to attain a higher ultimate capacity.

A second comparison was performed at elevated temperatures, using HSS of 460, 690 and $960 \mathrm{MPa}$, as well as FR steels in this range of strengths for the inner and outer tube. As it can be seen in Fig. 8, as the yield strength of the tubes is increased, the fire resistance time of the composite columns also increase. An increase in fire resistance time from 87 minutes to 115 minutes is observed when the steel grade is changed from S355 to S960. Fig. 8 also shows that as the steel grade of the outer tube is increased, a progressive delay of its yielding is observed, which is reflected in these curves as the point where the maximum expansion and subsequent drop of the axial displacement occurs.

This increase is more noticeable when using FR steels (Fig. 9), reaching a fire resistance time of 126 minutes for the case with 960 MPa FR steel in the tubes, although it should be noted that the increase obtained with FR steel as compared to HSS is marginal.

Related to geopolymer concrete, additional numerical tests were developed using concrete with a lower conductivity of $0.43 \mathrm{~W} / \mathrm{m} \cdot \mathrm{K}$, while the steel grade of the tubes was maintained equal to $355 \mathrm{MPa}$. Fig. 10 shows the fire response of each specimen with geopolymer concrete placed in different positions. While the original double-tube column, 
Espinos A, Romero ML*, Hospitaler A, Pascual AM, Albero V, “Advanced materials for concrete-filled tubular columns and connections “, Structures 2015; 4: 105-113. http://dx.doi.org/10.1016/j.istruc.2015.08.006

without geopolymer concrete, reaches a fire resistance time of 87 minutes, those columns with geopolymer concrete placed at the ring between the outer and the inner steel tube increase their fire resistance time up to 139 minutes. This increase in fire resistance is due to the delay in the temperature rise of the inner tube provided by the outer ring of geopolymer concrete, showing a lower slope in the second axial displacement increase. These specimens also reach the outer tube yielding earlier, since the geopolymer concrete with lower conductivity causes a faster increase of the outer tube temperatures. In turn, the worst fire performance is shown by the double-tube with geopolymer concrete placed at the inner core, as in this case a faster temperature rise at the inner tube occurs. In this last case the geopolymer concrete, placed in that position, does not cause an improvement on the fire resistance of the column, however when it is placed between the outer and the inner tube the double-tube column reaches a noticeable fire resistance improvement. Therefore, using geopolymer concrete in double-tube columns can provide an enhanced fire resistance depending on where it is placed. It is noticeable that a higher fire resistance time, 139 minutes, can be reached applying geopolymer concrete in double-tubes, placed correctly, which exceeds that obtained using 960 MPa FR steel in the tubes, 126 minutes.

Finally, in order to assess the application of advanced materials in other different CFST columns and their fire resistance, the reference column C3 shown in Fig. 4a was used. In this case FR steel and geopolymer concrete with low conductivity were applied in a CHS column, showing the behaviour plotted in Fig. 11. It can be seen that for this type of CFST section these advanced materials have no benefits in its fire response. In fact, the specimen with geopolymer concrete shows an earlier buckling of the steel tube because of its faster temperature increase. On the other hand, the fire resistant steel applied in a specimen with normal concrete delays the outer tube yielding but reaching a similar fire resistance time than the reference specimen. 
Espinos A, Romero ML*, Hospitaler A, Pascual AM, Albero V, “Advanced materials for concrete-filled tubular columns and connections “, Structures 2015; 4: 105-113. http://dx.doi.org/10.1016/j.istruc.2015.08.006

Therefore, advanced materials, which help double-tube columns to reach higher fire resistance times, have no effect applied to conventional CFST columns.

All these conclusions are the first approach of this study, focused on the advantages of using advanced materials on CFT columns. In this case a deeper assessment about costs of these solutions was not carried out, because probably as advanced materials such as HS and FR steels or geopolymer concrete are not economically competitive at present against normal steel and concrete. However, through their future development, they might become competitive materials which can result very useful for double-tube CFT columns, as was proved in this research work.

\section{IMPROVEMENT OF BLIND-BOLT CONNECTIONS}

\subsection{General}

The effect of the innovative materials on the connections performance was studied by means of numerical models, which were previously validated with experiments by the authors [37]. Three-dimensional FE models were developed by using the commercial program ABAQUS [38].

For simplicity, a single blind-bolt clamping a loading frame plate and the tube column was studied (Fig. 12). Tensile force was transmitted to blind-bolts through the rigid loading frame plate, $30 \mathrm{~mm}$ thick. The tubular column wall was $20 \mathrm{~mm}$ thick. These values of thickness were projected in order to focus the attention on the blind-bolts performance which controlled the behaviour of the connection. Hollo-bolt was the fastener system used in the connections, created by Lindapter [39]. It consists of 5 different elements (Fig. 13): a standard bolt, a collar, a high clamping force mechanism, a cone and a sleeve with four slots. For the numerical 
Espinos A, Romero ML*, Hospitaler A, Pascual AM, Albero V, “Advanced materials for concrete-filled tubular columns and connections “, Structures 2015; 4: 105-113. http://dx.doi.org/10.1016/j.istruc.2015.08.006

analysis the blind -bolt was simplified into two parts, the shank and the sleeve Fig. 14. The standard bolt was M16 grade $8.8\left(\mathrm{f}_{\mathrm{y}}=640 \mathrm{MPa} ; \mathrm{f}_{\mathrm{u}}=800 \mathrm{MPa}\right)$ with a shank of $100 \mathrm{~mm}$ in length .

Two cases were considered, connections to a hollow steel section column and to a CFST column (Fig. 12)

\subsection{Fire resistant steel bolts}

The thermo-mechanical response of the connections was studied, which involved the pull-out loading of the bolt while it was exposed to the standard fire curve ISO834 [40]. The fire resistant rating (FRR), or the time in minutes that the connection is capable of sustaining the load before the failure occurs, was analysed, whose value resulted highly linked to the failure mode of the connection. The increase of the FRR achieved using FR steel bolts was determined by comparison with normal HSS bolts. FR steel bolts properties were defined following the recommendations from Sakumoto et al. [27], while HSS capacity was extracted from Eurocode 3 Part 1.2 Annex D [41]

In a previous work from the authors, Pascual et al [9], it was observed that in connections to hollow steel columns in fire, at the failure instant, stresses exceeded the capacity of both, sleeve and shank. Nonetheless, in connections to CFST columns, the sleeve underwent less stresses and the shank was the compromising part for the connection. As a consequence, the enhancement of using Fire Resistant bolts was significant in the case of connections to CFST, where the FRR went from around 24.68 minutes to 28.83 minutes (17\% increase), see Table 1. Meanwhile, in the connections to hollow steel sections, the effect by using FR steel bolts is negligible since the sleeve is failing and the change in bolt properties does not affect the final failure. 
Espinos A, Romero ML*, Hospitaler A, Pascual AM, Albero V, “Advanced materials for concrete-filled tubular columns and connections “, Structures 2015; 4: 105-113. http://dx.doi.org/10.1016/j.istruc.2015.08.006

Eventually, the differences between HSS bolts and FR steel bolts were not very high, but, under certain circumstances, they could represent the necessary increase to comply with the fire requirements of the structure.

\subsection{Shape memory alloys}

The same blind-bolted connection was studied under cyclic loads at room temperature. The objective was accomplishing a preliminary comparison of the connection performance with blind-bolts whose shank is SMA with superelastic properties in contrast to HSS bolts (M16 grade 8.8)

A pull-out load was applied to the bolt through the displacement of the load frame. The protocol followed for the cycles of loading was the same used by DesRoches et al. [28] (Fig. 15) which considers a first cycle of $0.5 \%$ in strain, five cycles from 1 to $6 \%$ at an increment of $1 \%$ and four last cycles of $6 \%$. The SMAs properties associated to the superelastic effect were extracted from Fang et al [29], Fig. 16 and Table 2. For SMA's characterization in ABAQUS, a superelastic user-defined material model was utilised, which considers Auricchio’s proposal [42]

The stress-strain laws for the bolt shank of both connections, to hollow and CFST columns, were extracted in Fig. 17a and Fig. 17b, where the deformation recovery experimented by the SMA bolts is evidenced. Conversely, for the HSS bolts, plastic strains remained after the unloading. The higher capacity and stiffness linked to the material properties of the HSS bolts was also proved, besides the higher ductility of SMA bolts.

At the end of the loading cycle the stress distribution in connections to hollow sections and SMA bolts from Fig. 18a showed that stresses concentrated in the sleeve and the cone but not in the shank. On the contrary, with HSS bolts the stresses in shank were higher than the $f_{y}$ and close to $f_{u}$, the damage in the sleeve was important as well (Fig. 18b). As a result, plastic 
Espinos A, Romero ML*, Hospitaler A, Pascual AM, Albero V, “Advanced materials for concrete-filled tubular columns and connections “, Structures 2015; 4: 105-113. http://dx.doi.org/10.1016/j.istruc.2015.08.006

strains in SMA connections appeared only in the folded section of the sleeve (Fig. 18c), while both shank and sleeve were undergoing large plastic strains in HSS bolt connections (Fig. 18d)

Similarly to connections to hollow columns, stress distribution in connections to CFST columns indicated (Fig. 19a) the scarce stresses in the shank when using SMA bolts. At the end of the loading, only stresses appeared significantly in the sleeve. For the HSS bolts, the shank together with the sleeve experimented stresses close to $f_{u}$, as it is shown in Fig. 19b. Regarding deformation, some plastic strains due to the cracking and crushing of the concrete were observed for the SMA bolts in the CFST column connections (Fig. 19c). On the other hand, the affected volume and the values of plastic strains in concrete were considerably important using HSS bolts, with also high plastic strains in the shank and sleeve (Fig. 19d).

\section{CONCLUSIONS}

Through this work, several strategies focused on the use of innovative materials have been studied, aiming to increase the capacity of CFST columns and connections to hollow and CFST columns at both room and elevated temperatures. For the CFST columns, the use of HSS, FR steel and geopolymer concrete has been analysed and the main conclusions are:

- HSS placed in the outer tube is an effective solution to increase the maximum capacity for axially loaded double-tube columns at room temperature.

- Both HSS and FR steel applied in the inner tube, as well as geopolymer concrete placed at the ring between the outer and the inner tube, increase the double-tube columns fire resistance time.

- Advanced materials in the fire situation, like FR steel and geopolymer concrete, which help double-tube columns to reach higher fire resistance time, have no significant effect applied to conventional CFST columns. 
Espinos A, Romero ML*, Hospitaler A, Pascual AM, Albero V, “Advanced materials for concrete-filled tubular columns and connections “, Structures 2015; 4: 105-113. http://dx.doi.org/10.1016/j.istruc.2015.08.006

Besides, blind-bolted connections to CFST columns under fire were found to present a limited capacity due to the deterioration of the bolt shank. The use of FR steel bolts will allow a slight increase (20\%) which can result of significant importance depending on the fire requirements.

Under cyclic loads, the superelastic effect of SMA is a promising property to be considered in blind-bolted connections. Their capacity to recover the deformation permits them to return to their initial state at the same time that the rest of the elements do not suffer as much damage as using high strength steel bolts. The present study represents an initial approach to the possibilities offered by these alloys.

\section{ACKNOWLEDGEMENTS}

The authors would like to express their sincere gratitude to the Spanish Ministry of Economy and Competitivity through the project BIA2012-33144 and to the European Union for the FEDER funds.

\section{REFERENCES}

[1] Romero, M.L., Moliner, V., Espinos, A., Ibañez, C., Hospitaler, A. Fire behavior of axially loaded slender high strength concrete-filled tubular columns, Journal of Constructional Steel Research 2011; 67:1953-1965.

[2] Moliner V, Espinos A, Romero ML, Hospitaler A. 2013. Fire behavior of eccentrically loaded slender high strength concrete-filled tubular columns. Journal of Constructional Steel Research 2013; 83:137-146.

[3] Espinos A. Numerical analysis of the fire resistance of circular and elliptical slender concrete filled tubular columns. Doctoral thesis. Valencia, Spain: Universitat Politècnica de València; 2012. 
Espinos A, Romero ML*, Hospitaler A, Pascual AM, Albero V, “Advanced materials for concrete-filled tubular columns and connections “, Structures 2015; 4: 105-113. http://dx.doi.org/10.1016/j.istruc.2015.08.006

[4] Espinos A, Romero M, Hospitaler A. Advanced model for predicting the fire response of concrete filled tubular columns. Journal of Constructional Steel Research 2010; 66(89):1030-1046.

[5] Zhao X, Han L. Double skin composite construction. Progress in Structural Engineering and Materials 2006; 8(3):93-102

[6] Elchalakani M, Zhao XL, Grzebieta R. Tests on concrete filled double-skin (CHS outer and SHS inner) composite short columns under axial compression. Thin-Walled Structures 2002; 40(5):415-441.

[7] Lu H, Han L, Zhao X. Fire performance of self-consolidating concrete filled double skin steel tubular columns: Experiments. Fire Safety Journal 2010; 45(2):106-115.

[8] Romero M.L, Espinos A, Portolés J.M, Hospitaler A, Ibañez C. Slender double-tube ultrahigh strength concrete-filled tubular columns under ambient temperature and fire. Engineering Structures 2015; 99:536-545.

[9] Pascual AM, Romero ML, Tizani W. Fire performance of blind-bolted connections to concrete filed tubular columns in tension. Engineering Structures 2015,96:111-125.

[10] Pascual AM. Fire performance of blind-bolted connections to concrete filled tubular columns under tension. Doctoral thesis. Valencia, Spain: Universitat Politècnica de València; 2015.

[11] Qiang X. Behaviour of high strength steel endplate connections in fire and after fire. Doctoral thesis. Delft, Netherlands: Delft Academic Press; 2013.

[12] Lange J, Wohlfeil N. Examination of the mechanical properties of the microalloyed grain refined steel S460 at elevated temperatures. Bautechnik 2007; 84:711-720.

[13] Schneider R, Lange J. Constitutive equations of structural steel S460 at high temperatures. In: Nordic Steel Construction Conference 2009: 204-211. Sweden; 2009. 
Espinos A, Romero ML*, Hospitaler A, Pascual AM, Albero V, “Advanced materials for concrete-filled tubular columns and connections “, Structures 2015; 4: 105-113. http://dx.doi.org/10.1016/j.istruc.2015.08.006

[14] Outinen J. Mechanical properties of structural steels at high temperatures and after cooling down. Laboratory of Steel Structures, Helsinki University of Technology. Helsinki, Finland; 2007.

[15] Chen J, Young B, Uy B. Behaviour of high strength structural steel at elevated temperatures. Journal of Structural Engineering 2006; 132:1948-1954.

[16] Chiew SP, Zhao MS, Lee CK. Mechanical properties of heat-treated high strength steel under fire/post-fire conditions. Journal of Constructional Steel Research 2014; 98:12-19.

[17] Qiang X, Bijlaard F, Kolstein H. Dependence of mechanical properties of high strength steel S690 on elevated temperatures. Construction and Building Materials 2012; 30:73-79.

[18] Qiang X, Bijlaard F, Kolstein H. Deterioration of mechanical properties on high strength structural steel S460N under transient state fire condition. Materials and Design 2012; 40:521-527.

[19] Tondini N, Hoang VL, Demonceau JF, Franssen JM. Experimental and numerical investigation of high-strength steel circular columns subjected to fire. Journal of Constructional Steel Research 2013; 80:57-81.

[20] Zhao X, Heidarpour A, Gardner L. Recent developments in high-strength and stainless steel tubular members and connections. Steel Construction 2014; 7:65-72

[21] Committee on Fire Prevention and Fire Resistance. The Japan Iron and Steel Federation. Fire-resistant Steel. Steel Construction Today \& Tomorrow 2013; 12:15-16.

[22] Sakumoto YU, Saito H. Fire-Safe design of modern steel buildings in japan. Journal of Constructional Steel Research 1995; 33:101-123.

[23] Sakumoto Y, Yamaguchi T, Ohashi M, Saito H. High-temperature properties of fireresistant steel for buildings. Journal of Structural Engineering 1992; 118:392-407. 
Espinos A, Romero ML*, Hospitaler A, Pascual AM, Albero V, “Advanced materials for concrete-filled tubular columns and connections “, Structures 2015; 4: 105-113. http://dx.doi.org/10.1016/j.istruc.2015.08.006

[24] Ding J, Li GQ, Sakumoto Y. Parametric studies on fire resistance of fire-resistant steel members. Journal of Constructional Steel Research 2004; 60:1007-1027.

[25] Kelly FS, Sha W. A comparison of the mechanical properties of fire-resistant and S275 structural steels. Journal of Constructional Steel Research 1999; 50:223-233.

[26] Chung HY, Lee CH, Su WJ. Application of fire-resistant steel to beam-to-column moment connections at elevated temperatures. Journal of Constructional Steel Research 2010; 66:289-303.

[27] Sakumoto Y, Keira K, Furumura F, Ave T. Tests of fire-resistant bolts and joints. Journal of Structural Engineering 1993; 119(11):3131-50.

[28] DesRoches R, McCormick J, Delemont M. Cyclic Properties of Superelastic Shape Memory Alloy Wires and Bars. Journal of Structural Engineering 2004; 130:38-46.

[29] Fang C, Yam MCH, Lam ACC, Xie L. Cyclic performance of extended end-plate connections equipped with shape memory alloy bolts. Journal of Constructional Steel Reseach 2014; 94: 122-136.

[30] Yam MCH, Fang C, Lam ACC, Zhang Y. Numerical study and practical design of beamto-column connections with shape memory alloys. Journal of Constructional Steel Research 2015; 104: 177-192.

[31] Wang W, Chan TM, Shao H, Yiyi C. Cyclic behavior of connections equipped with NiTi shape memory alloy and steel tendons between H-shaped beam to CHS column. Engineering Structures 2015; 88: 37-50.

[32] Hu JW, Leon RT. Analyses and evaluations for composite-moment frames with SMA PRCFT connections. Nonlinear Dynamics 2011; 65:433-455.

[33] Zhang Z, Provis J.L, Reid A. Wang H. Geopolymer foam concrete: An emerging material for sustainable construction. Construction and Building Materials 2014; 56:113-127. 
Espinos A, Romero ML*, Hospitaler A, Pascual AM, Albero V, “Advanced materials for concrete-filled tubular columns and connections “, Structures 2015; 4: 105-113. http://dx.doi.org/10.1016/j.istruc.2015.08.006

[34] Kong D.L.Y, Sanjayan J.G. Effect of elevated temperatures on geopolymer paste, mortar and concrete. Cement and Concrete Research 2010; 40:334-339.

[35] Cheng T.W, Chiu J.P. Fire-resistant geopolymer produced by granulated blast furnace slag. Minerals Engineering 2003; 16:205-210.

[36] Espinos A, Romero M.L, Hospitaler A. Advanced model for predicting the fire response of concrete filled tubular columns. Journal of Constructional Steel Research 2010; 66:10301046.

[37] Pitrakkos T, Tizani W. Experimental behaviour of a novel anchored blind-bolt in tension. Engineering Structures 2013. 49(0): 905-919.

[38] Pawtucket RIH, Karlsson \& Sorenson, Inc. ABAQUS. ABAQUS/Standard Version 6.6 User’s Manual: Volumes I-III. 2005.

[39] Lindapter. Type HB - Hollo-Bolt. Cavity fixings 2, Product brochure. Lindapter International, UK. 2012: p 41-3.

[40] ISO 834: Fire resistance tests, elements of building construction. Switzerland: International Standards Organisation. 1980.

[41] CEN. EN 1993-1-2, Eurocode 3: Design of steel structures. Part 1-2: General rules Structural fire design. Brussels, Belgium: Comité Européen de Normalisation. 2005.

[42] Auricchio F, Taylor RL, Lubliner J. Shape memory alloys: macromodelling and numerical simulations of the superelastic behavior. Computer methods in applied mechanics and engineering 1997; 146:281-312. 


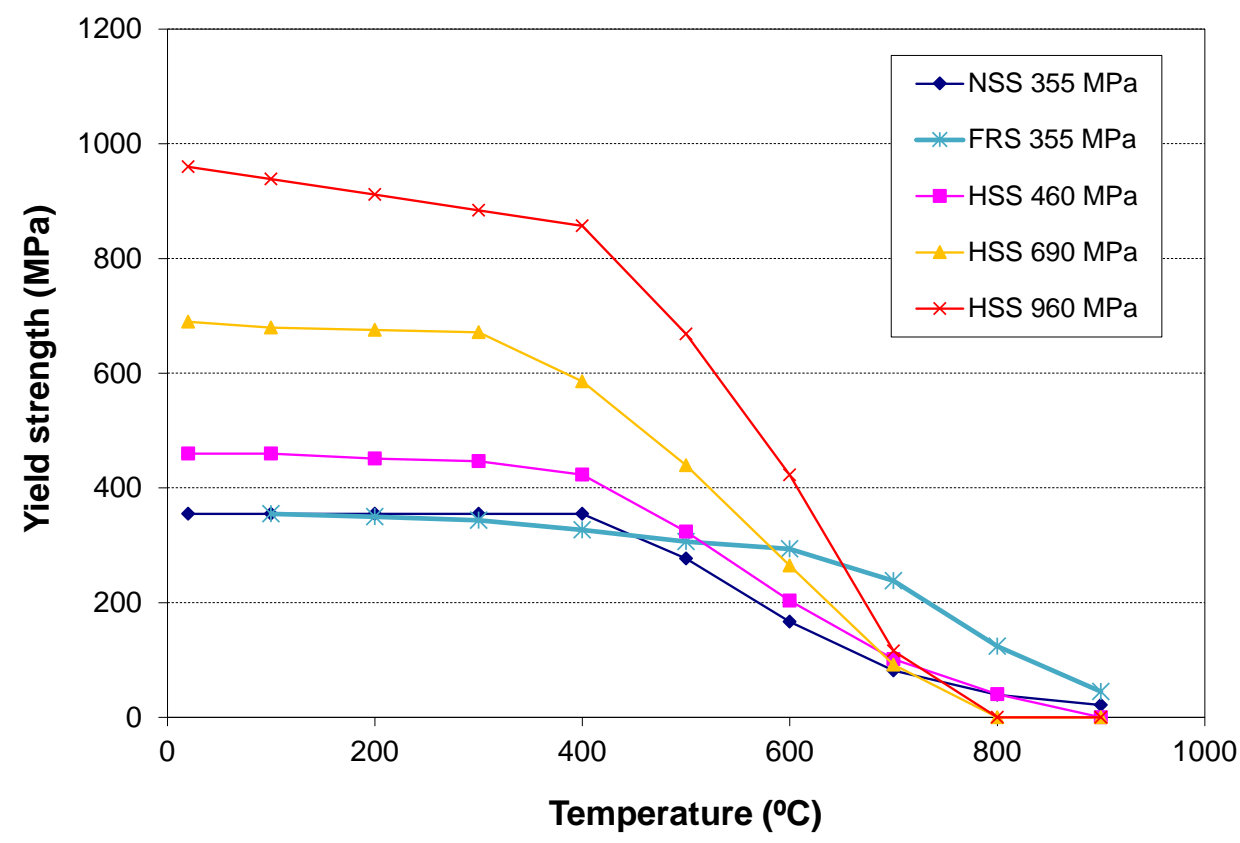

Fig. 1. Reduction of yield strength with temperature, for different steel grades. 


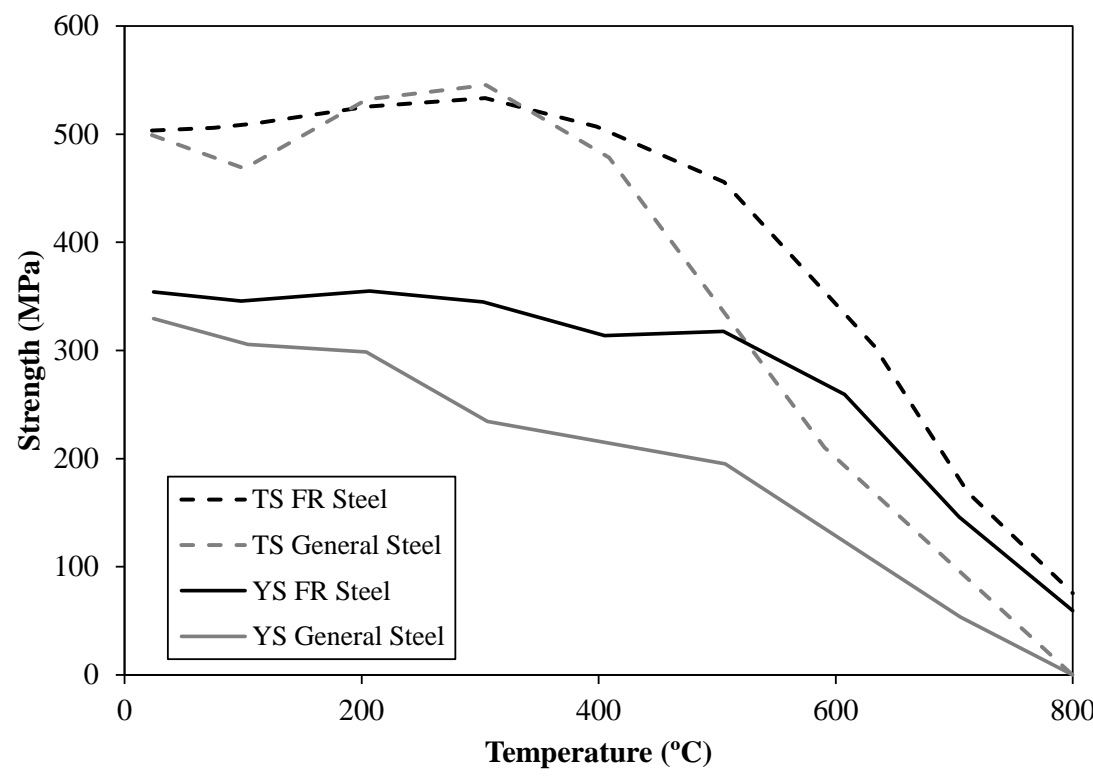

TS $=$ Tensile strength

YS $=$ Yield strength

Fig. 2. Comparison of the loss of strength with temperature of FR steels against general steels. Adapted from [22], [23]. 


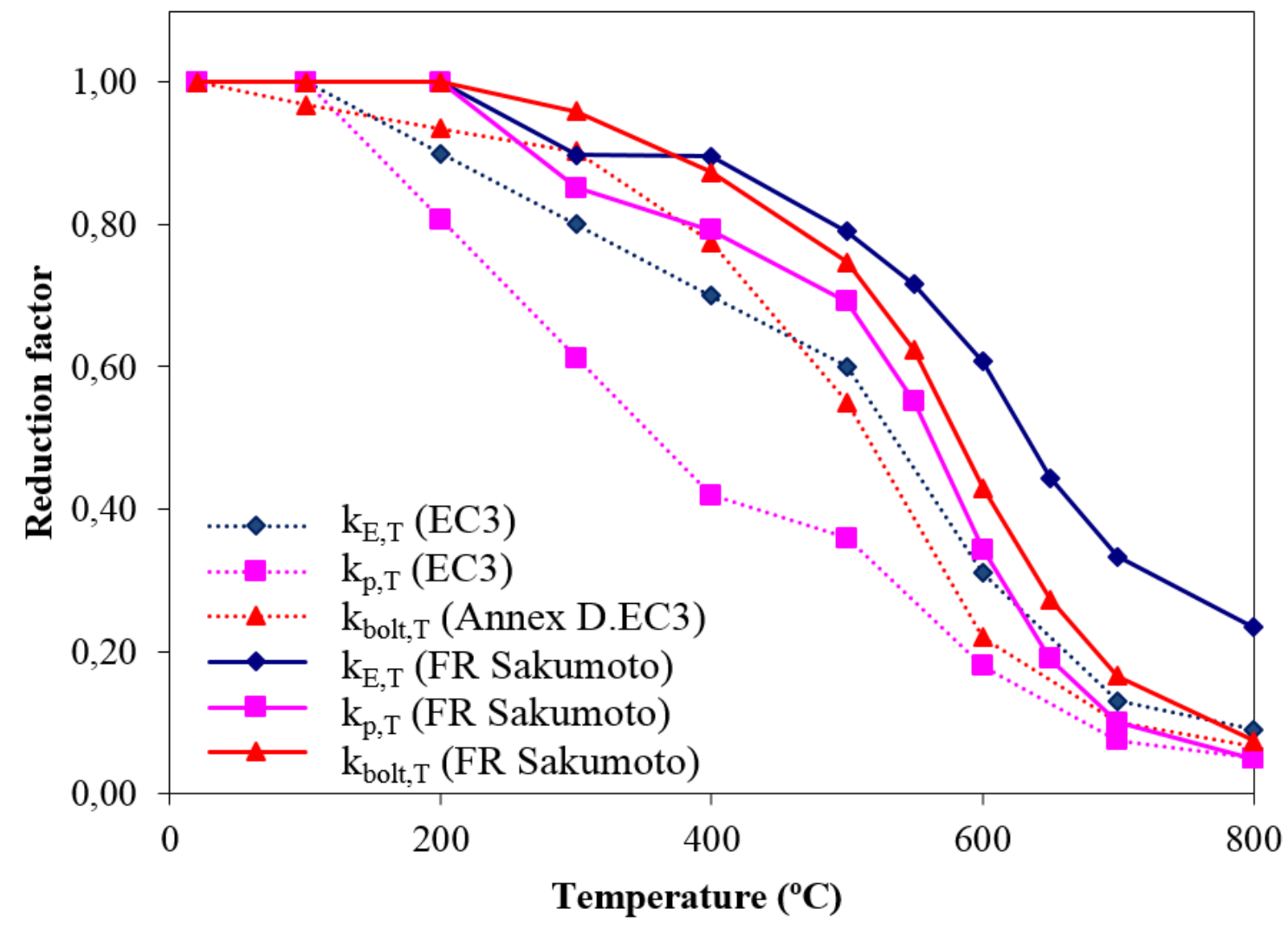

Fig. 3. Reduction factors from Eurocode 3 Part 1.2 Annex D [41] and for FR steel bolts from Sakumoto et al. [27] 
a)

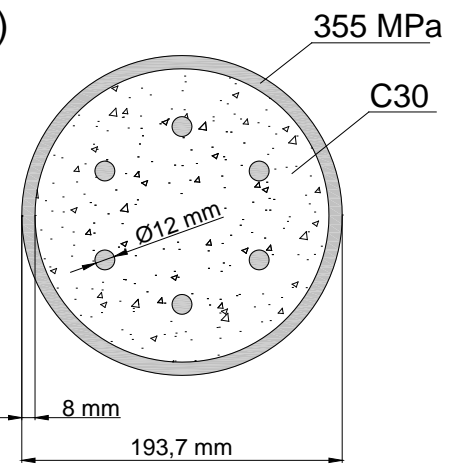

C3_C194-8-30

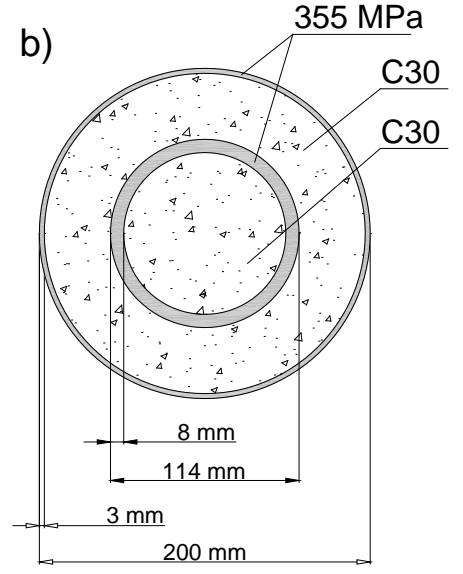

C200-3-30_C114-8-30

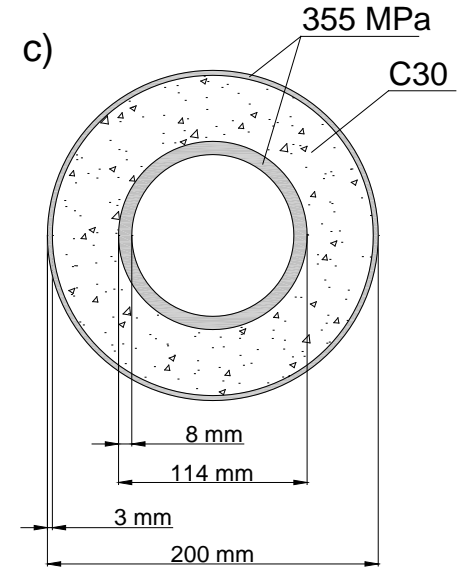

C200-3-30_C114-8-00

Fig. 4. Different cross-section configurations studied: a) concrete-filled CHS; b) double tube; c) double skin. 


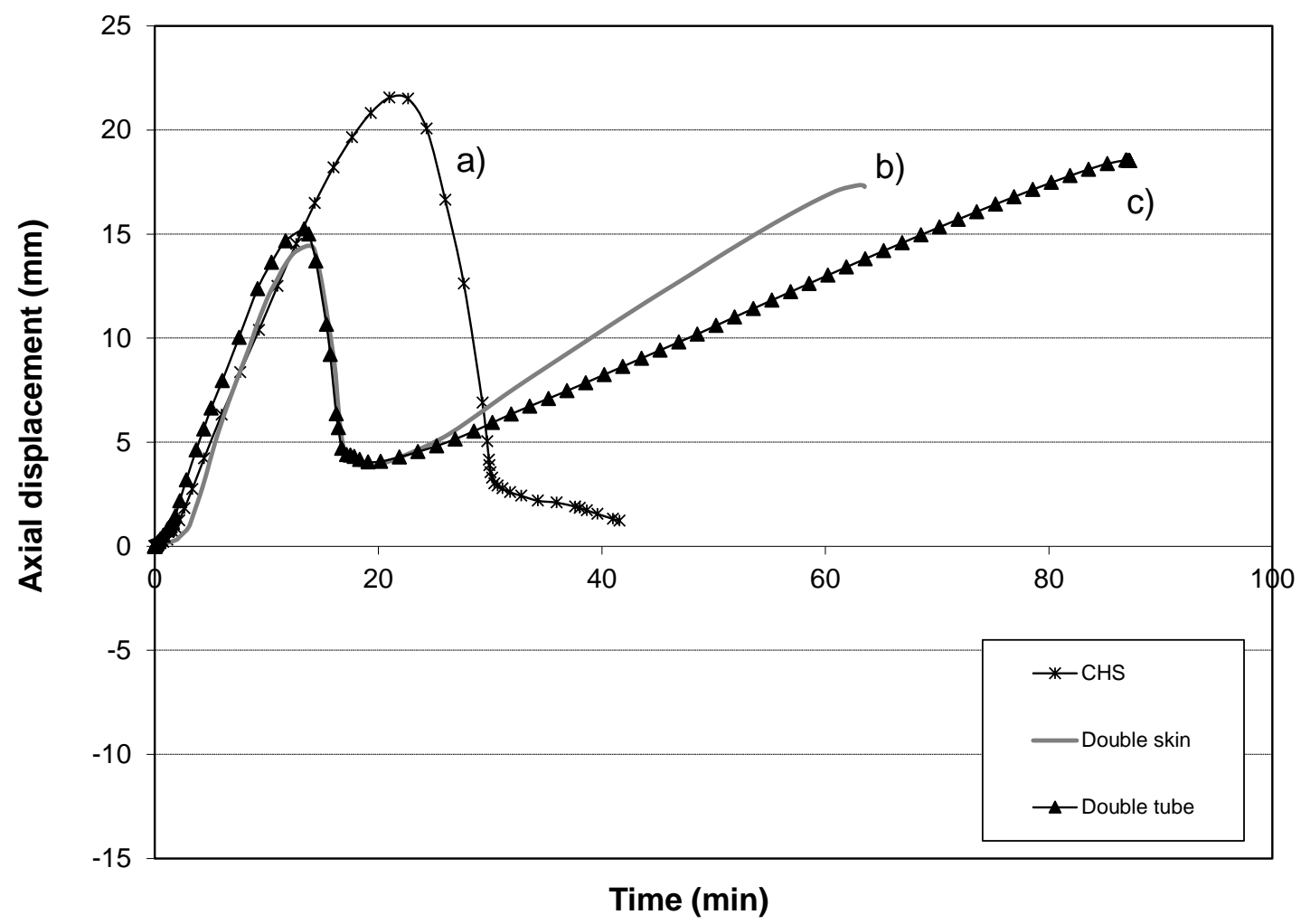

Fig. 5. Evolution of the axial displacement at the top end of the column, for the different crosssection configurations studied: a) concrete-filled CHS; b) double skin; c) double tube. 


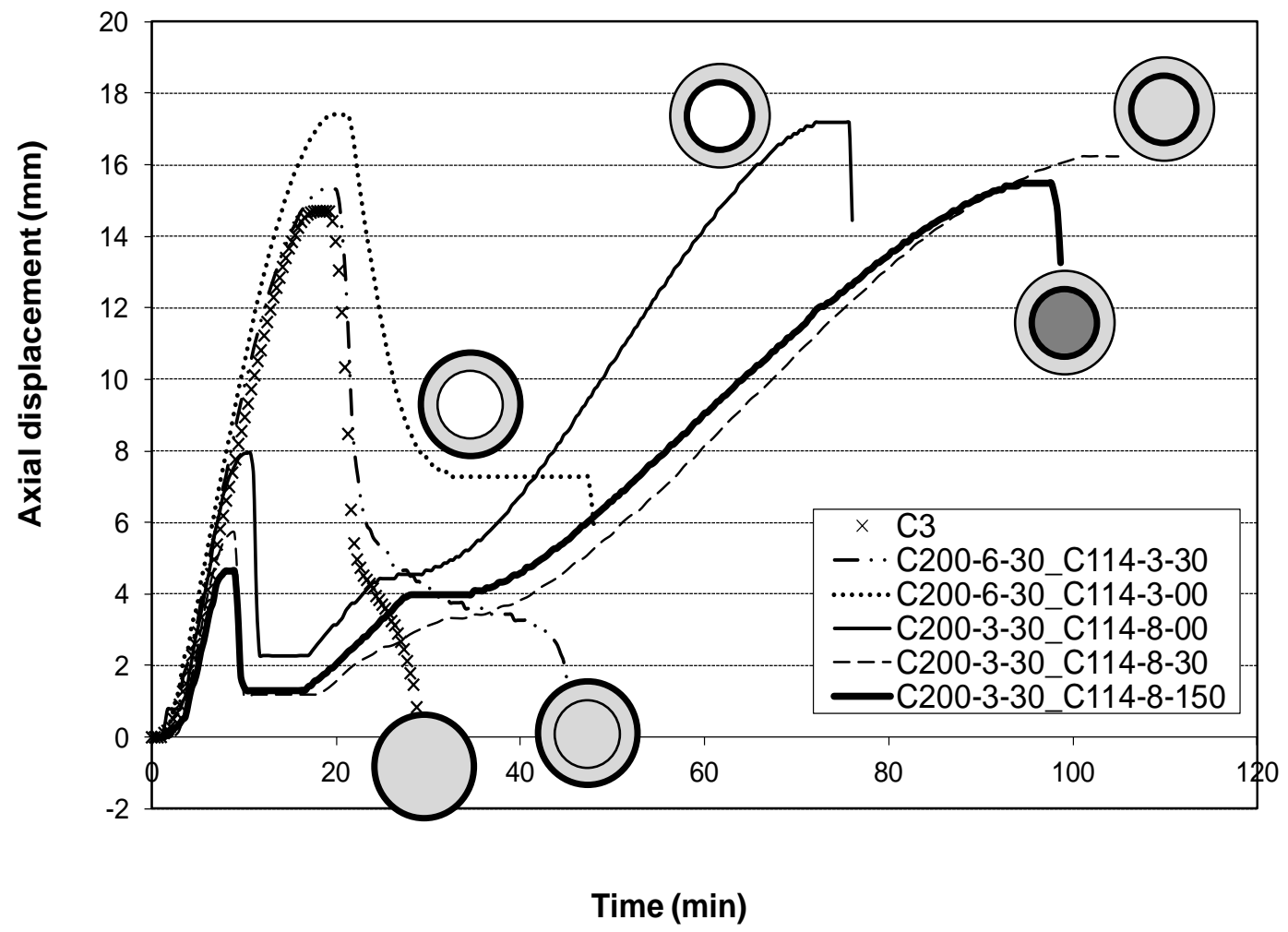

Fig. 6. Axial displacement versus time curves, for different configurations tested at elevated temperatures. [8] 


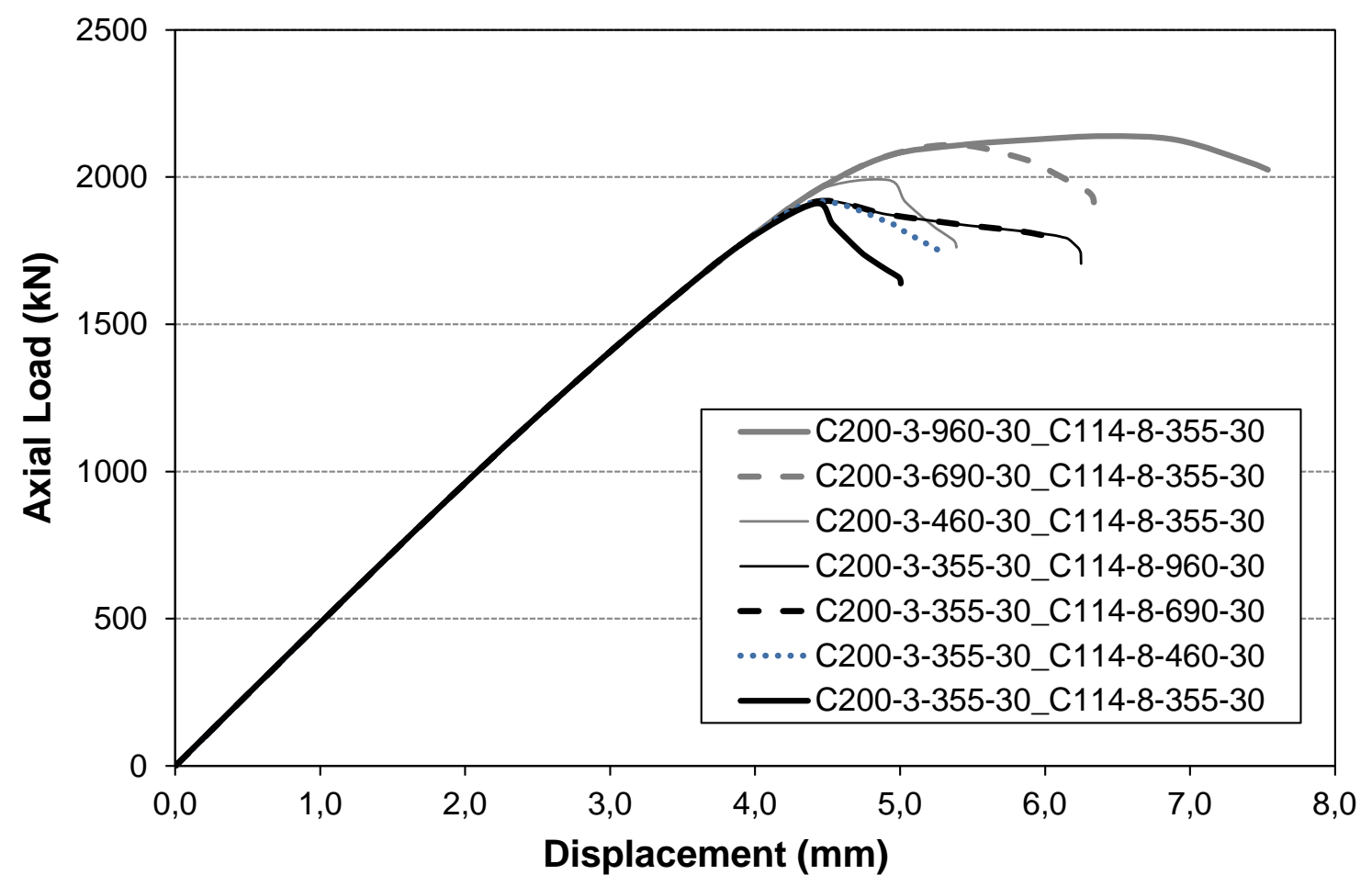

Fig. 7. Load versus axial displacement curves at room temperature, for the double tube specimen using different steel grades. 


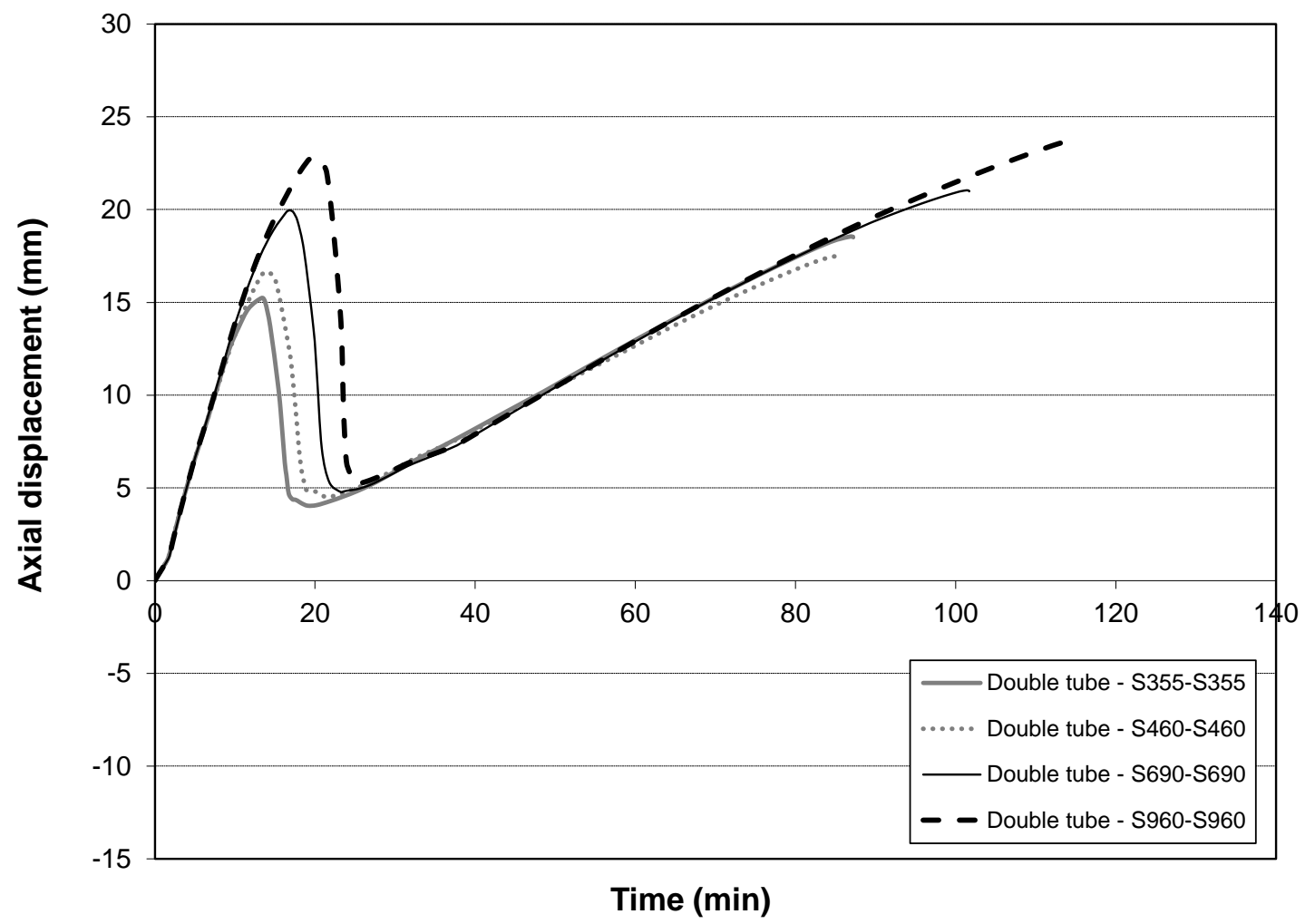

Fig. 8. Evolution of the axial displacement at the top end of the column, for the double tube specimen using different steel grades. 


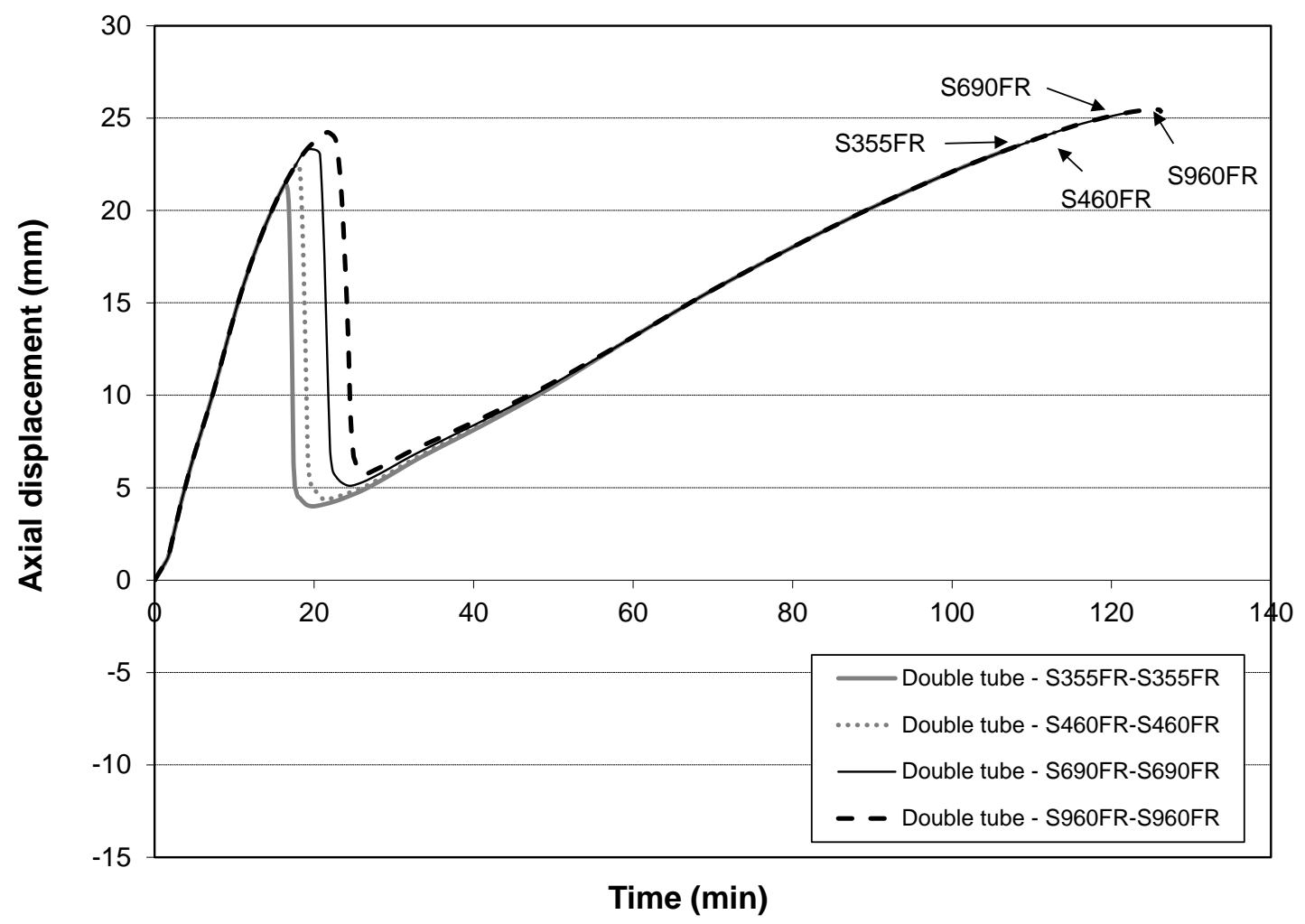

Fig. 9. Evolution of the axial displacement at the top end of the column, for the double tube specimen using fire resistant steels. 


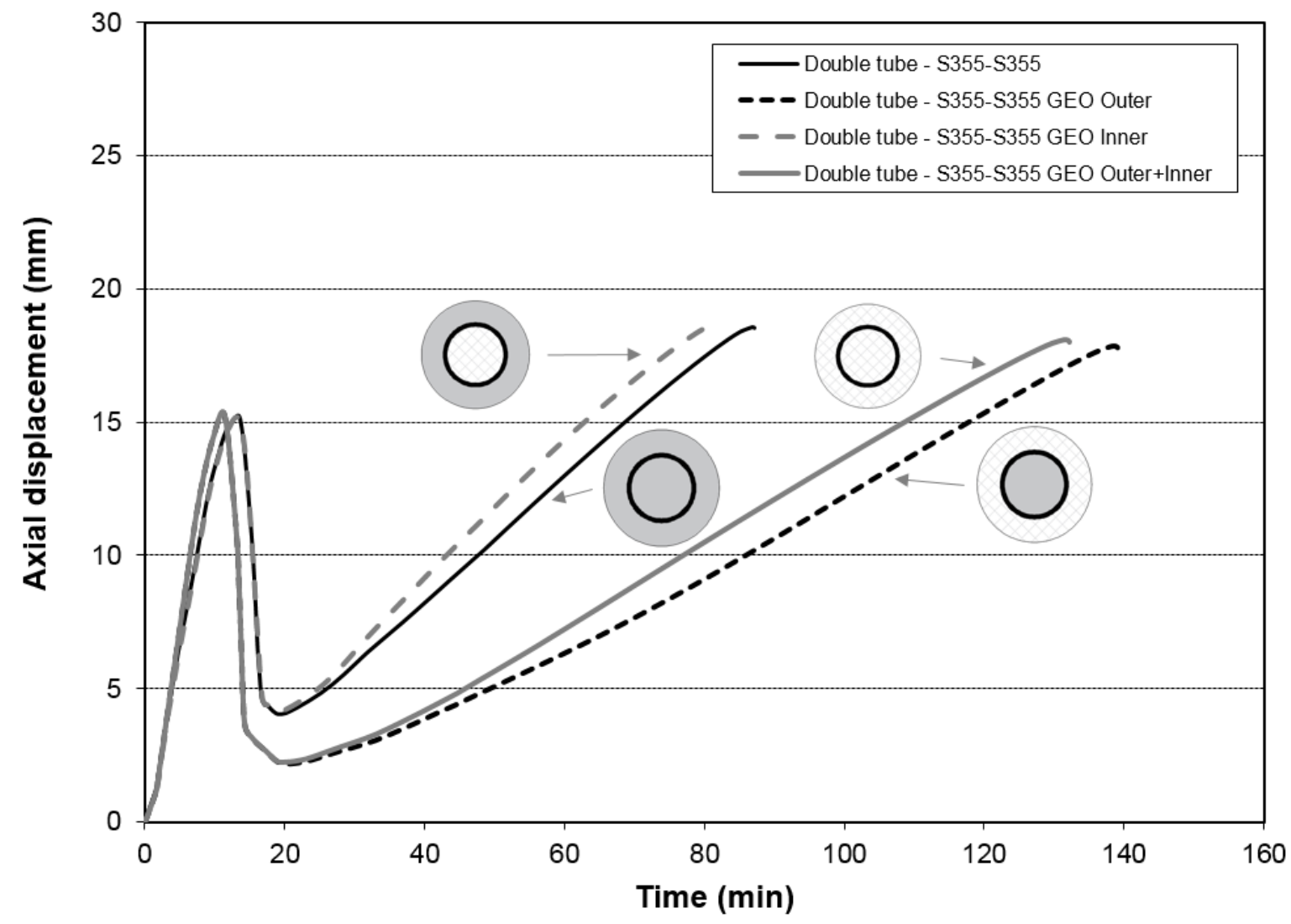

Fig. 10. Double-tube fire response using geopolymer concrete with lower conductivity. 


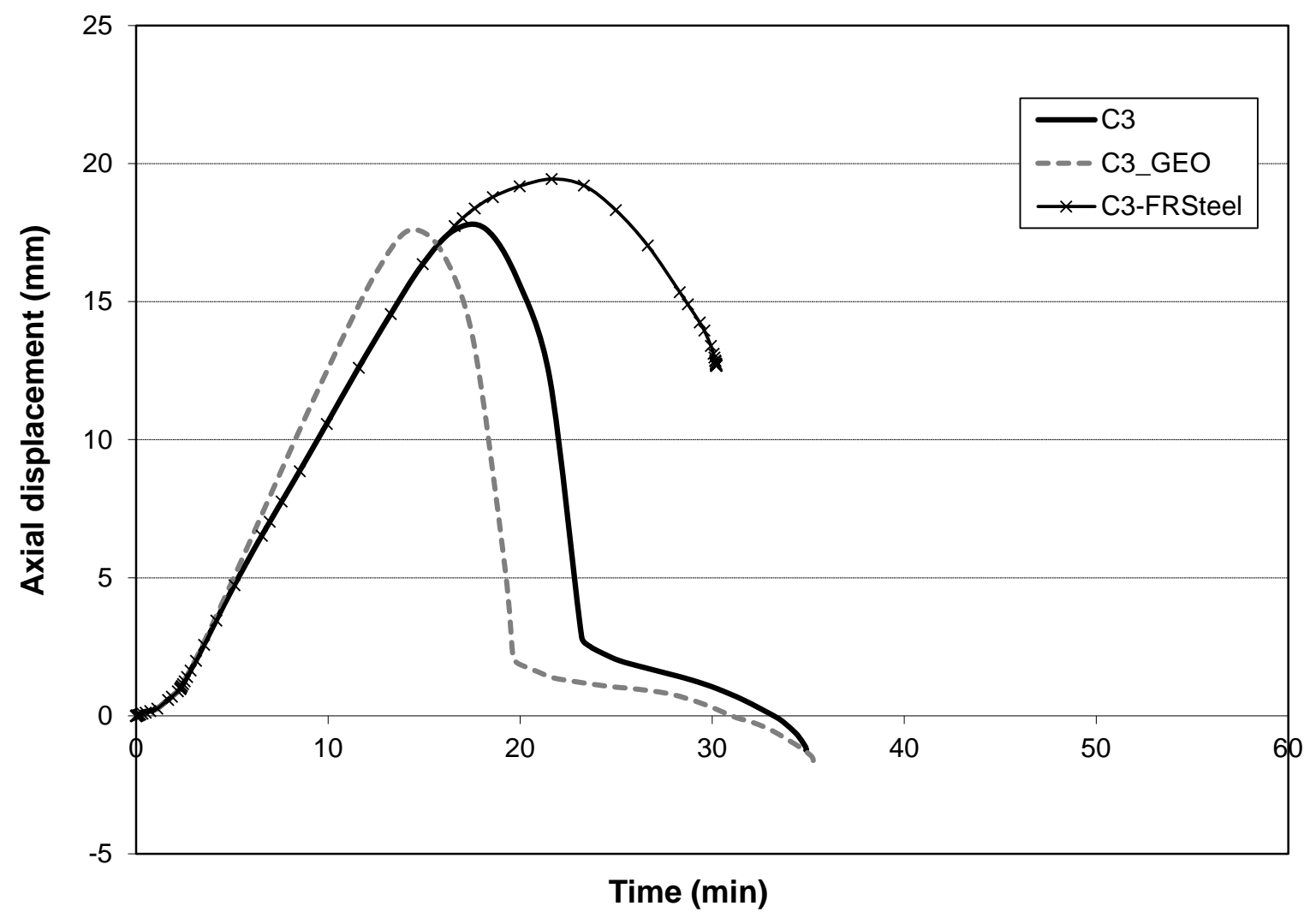

Fig. 11. Fire response of a CFT column using geopolymer concrete and fire resistant steel. 

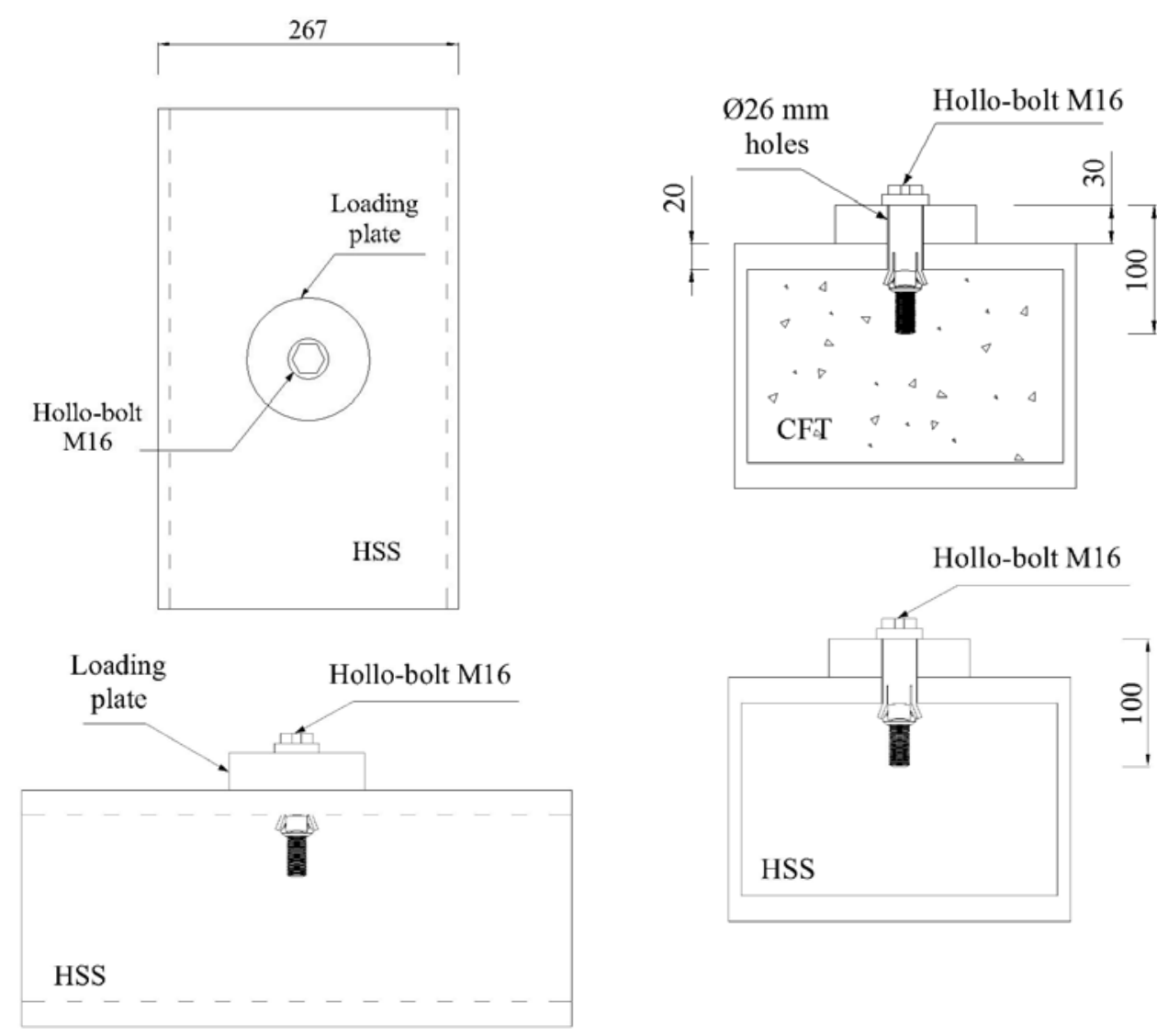

Fig. 12. Connection of a single blind-bolt [9] 


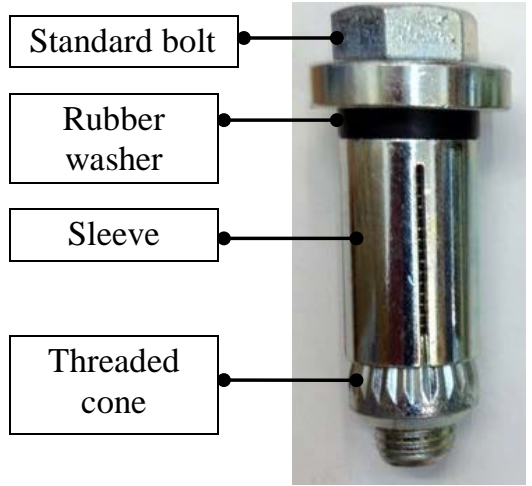

Fig. 13. Blind-bolts: Hollo-bolt [39] 


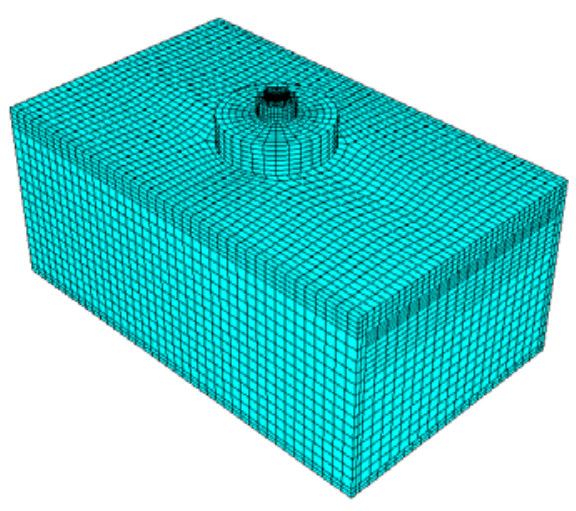

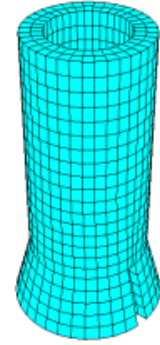

Sleeve

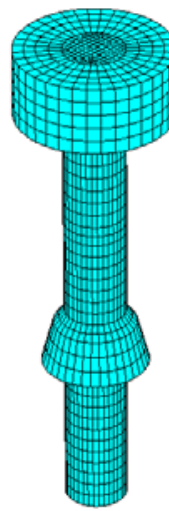

Shank

Fig. 14. Numerical model of the single blind-bolted connection at room temperature [9] 


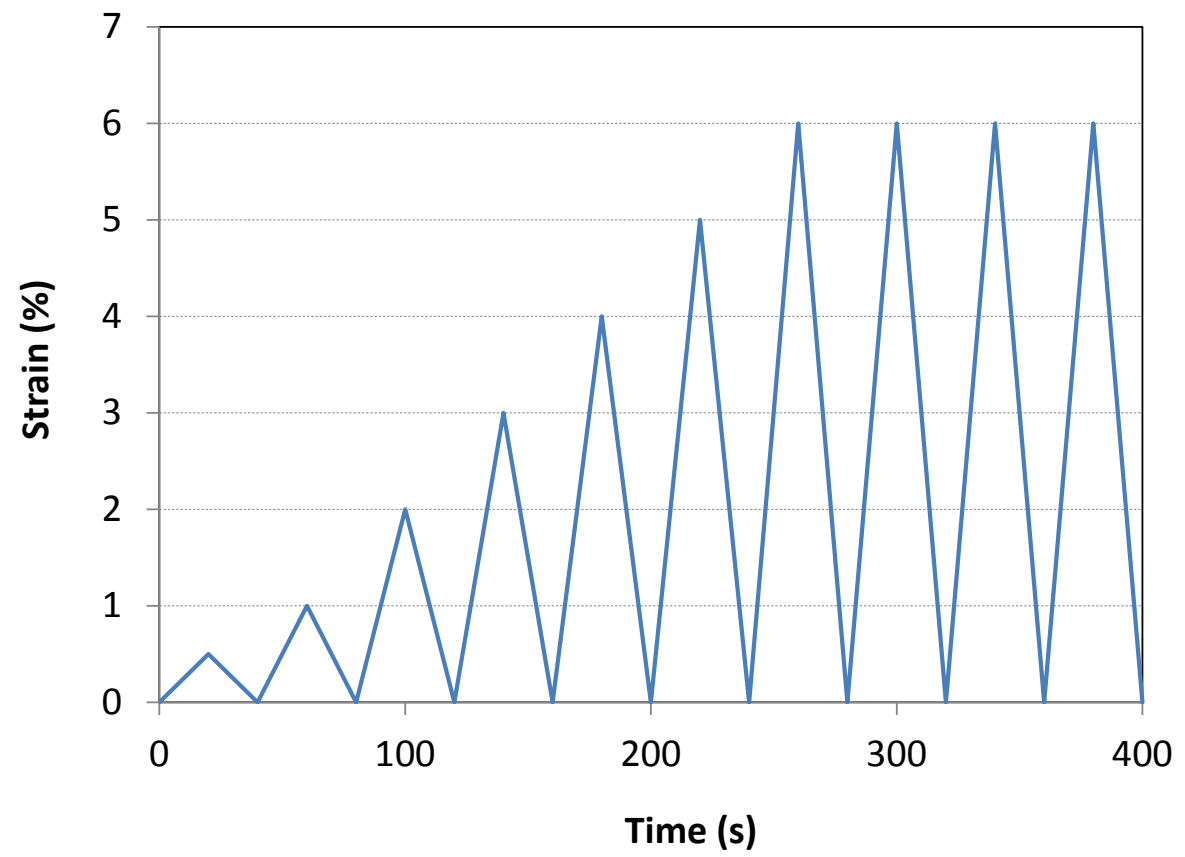

Fig. 15. Cyclic loading protocol for the analysis of SMAs in blind-bolted connections [28].

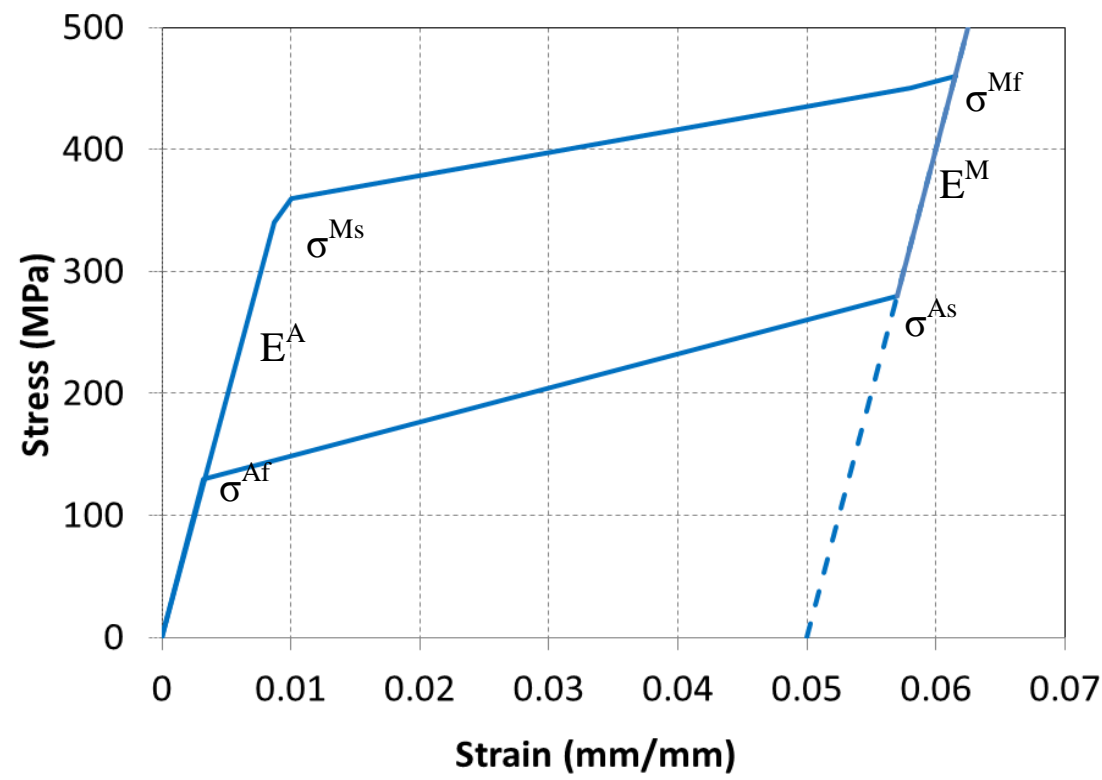

Fig. 16. Stress-strain law for SMAs. 
a)

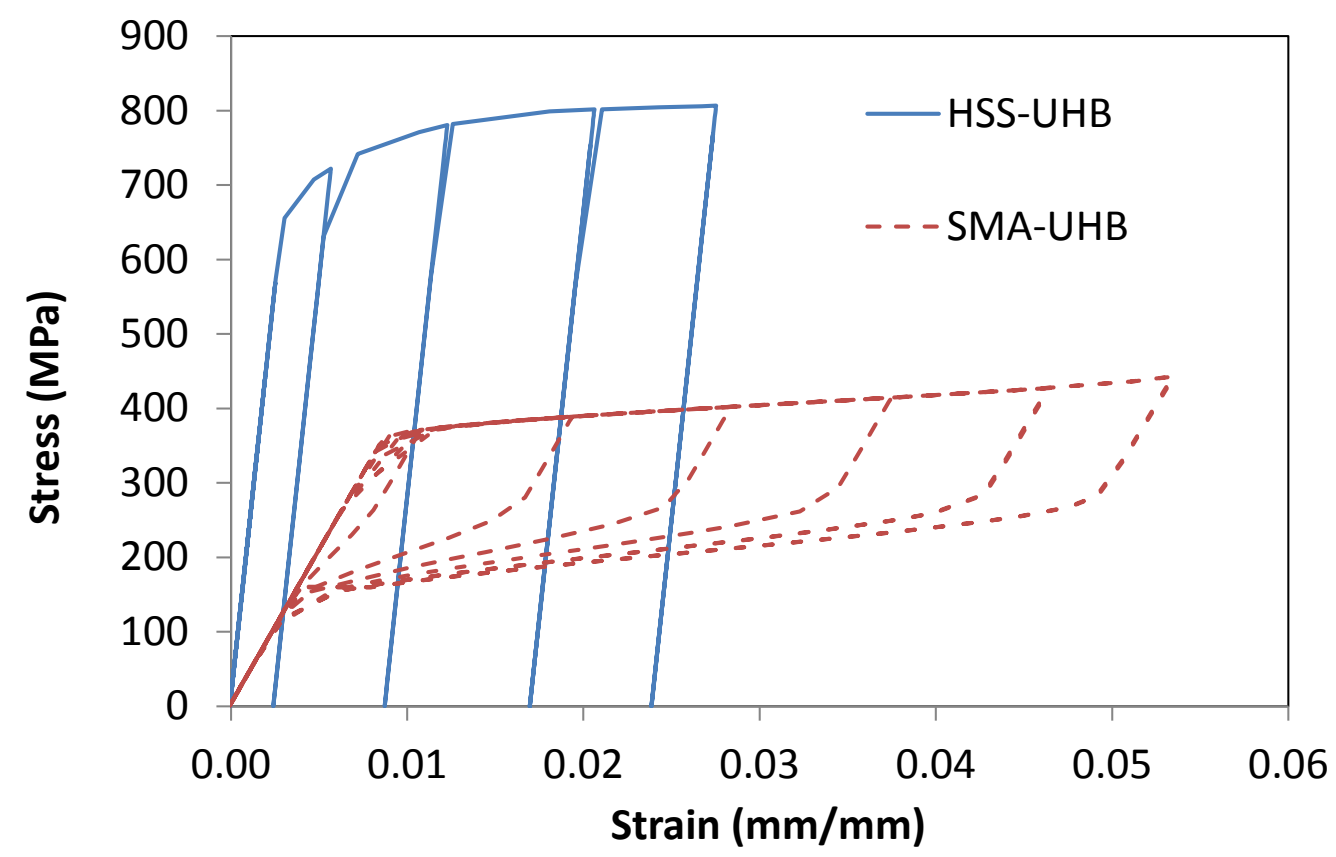

b)

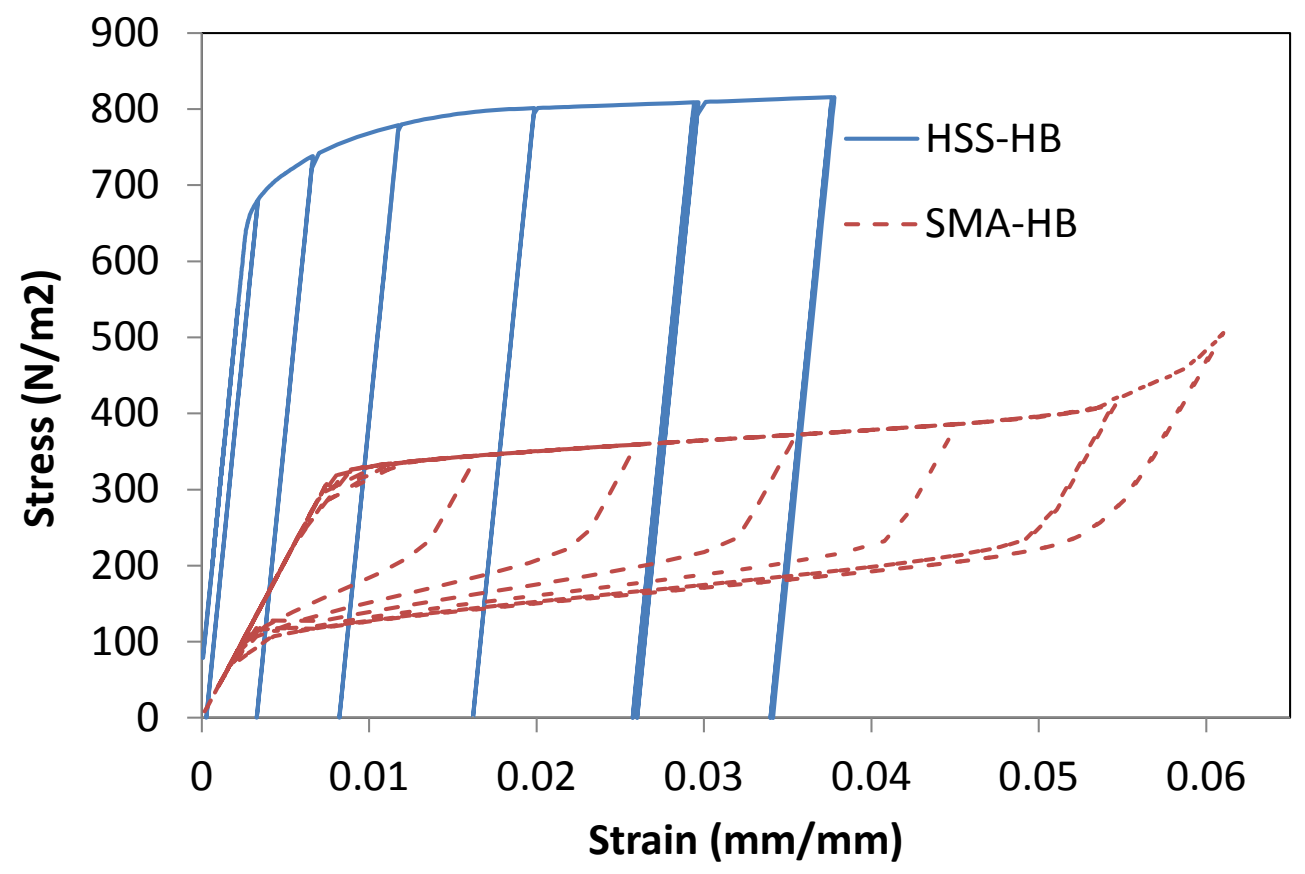

Fig. 17. Stress-strain response for blind-bolted connections to a) hollow steel section columns (Unfilled Hollo-Bolt connection. UHB); b) CFST columns (Hollo-Bolt connection. HB) 
a) SMA - Stress distribution

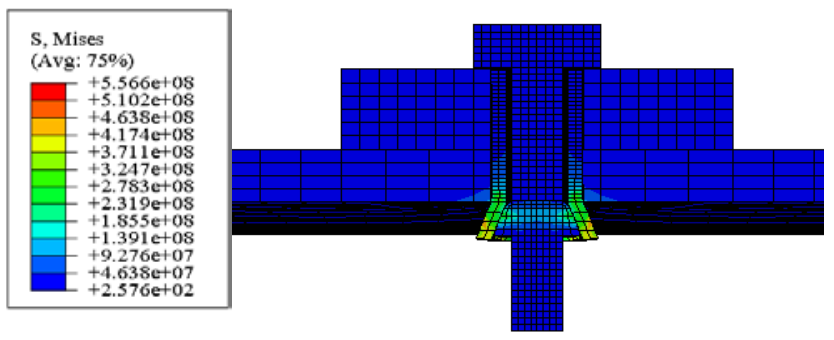

c) SMA - Plastic strain distribution

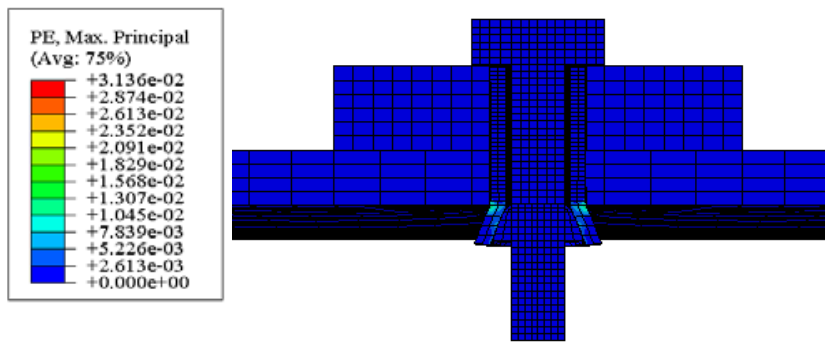

b) HSS - Stress distribution

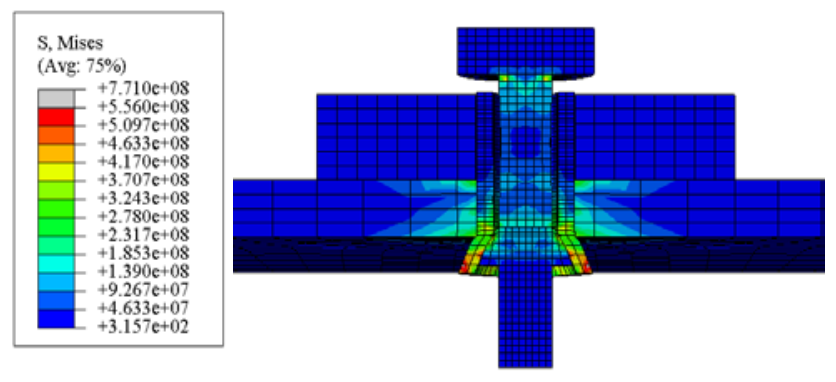

d) HSS - Plastic strain distribution

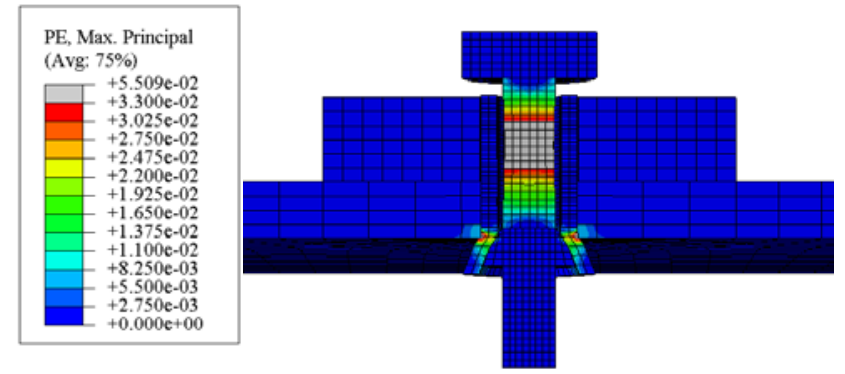

Fig. 18. Stress and plastic strain distribution in SMA and HSS bolts in connections to hollow steel section columns at the end of the loading cycle. 
a) SMA - Stress distribution

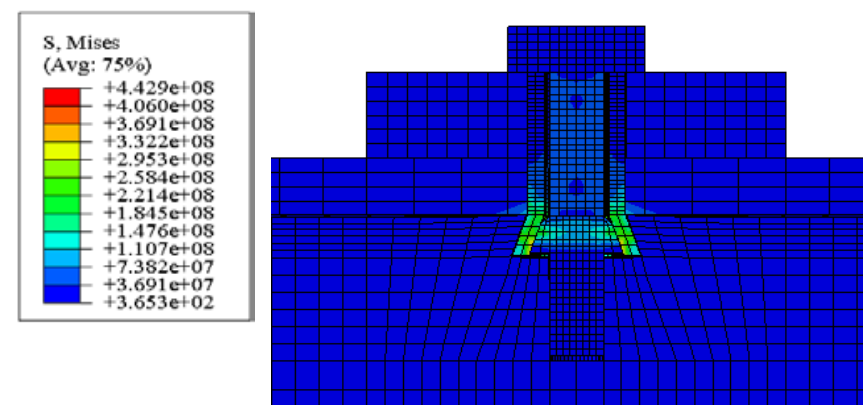

c) SMA - Plastic strain distribution

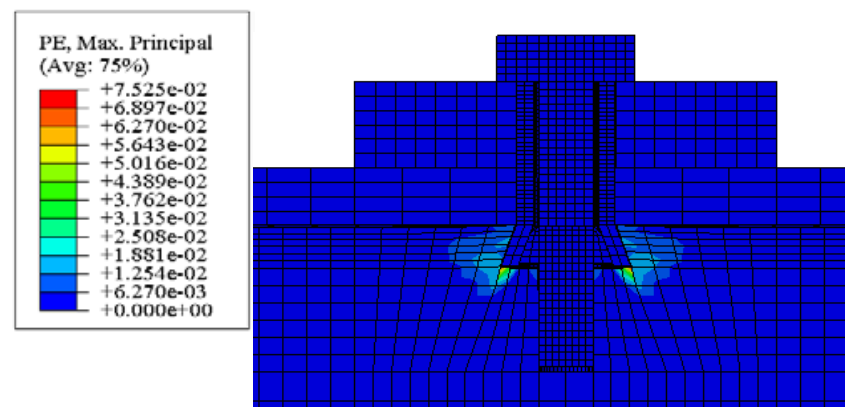

b) HSS - Stress distribution

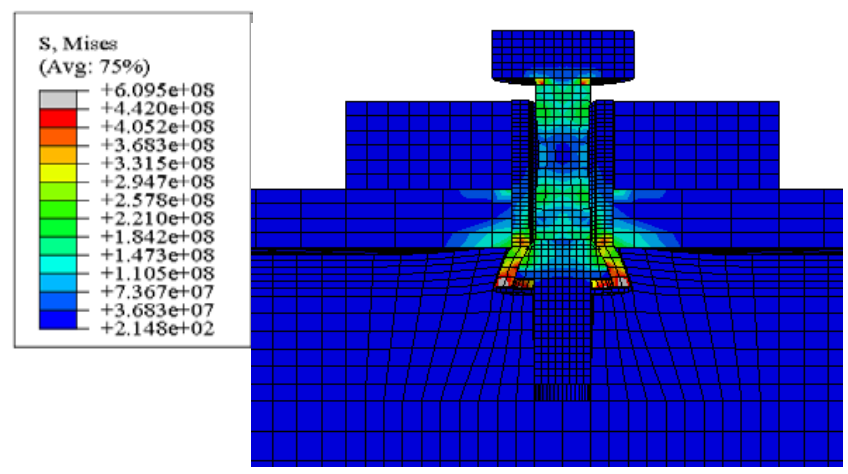

d) HSS - Plastic strain distribution

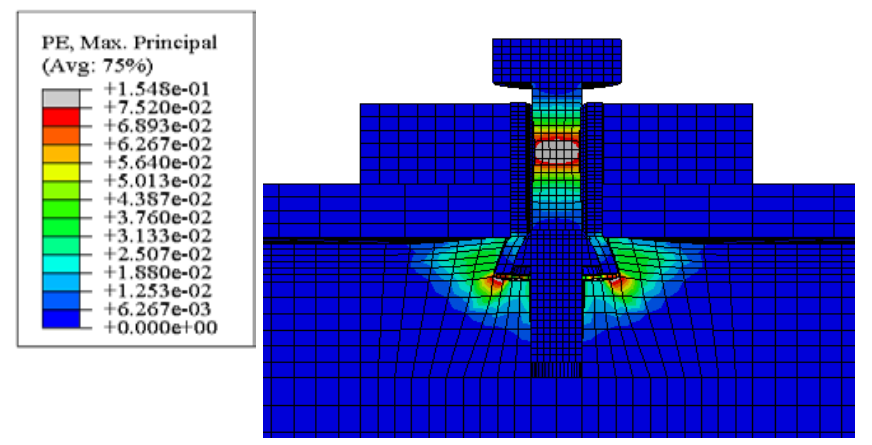

Fig. 19. Stress and plastic straind distribution in SMA and HSS bolts in connections to CFST columns at the end of the loading cycle. 
Table 1. Effect of using FR steel bolts on the fire resistance time of blind-bolted connections in comparison with high strength steel HSS bolts.

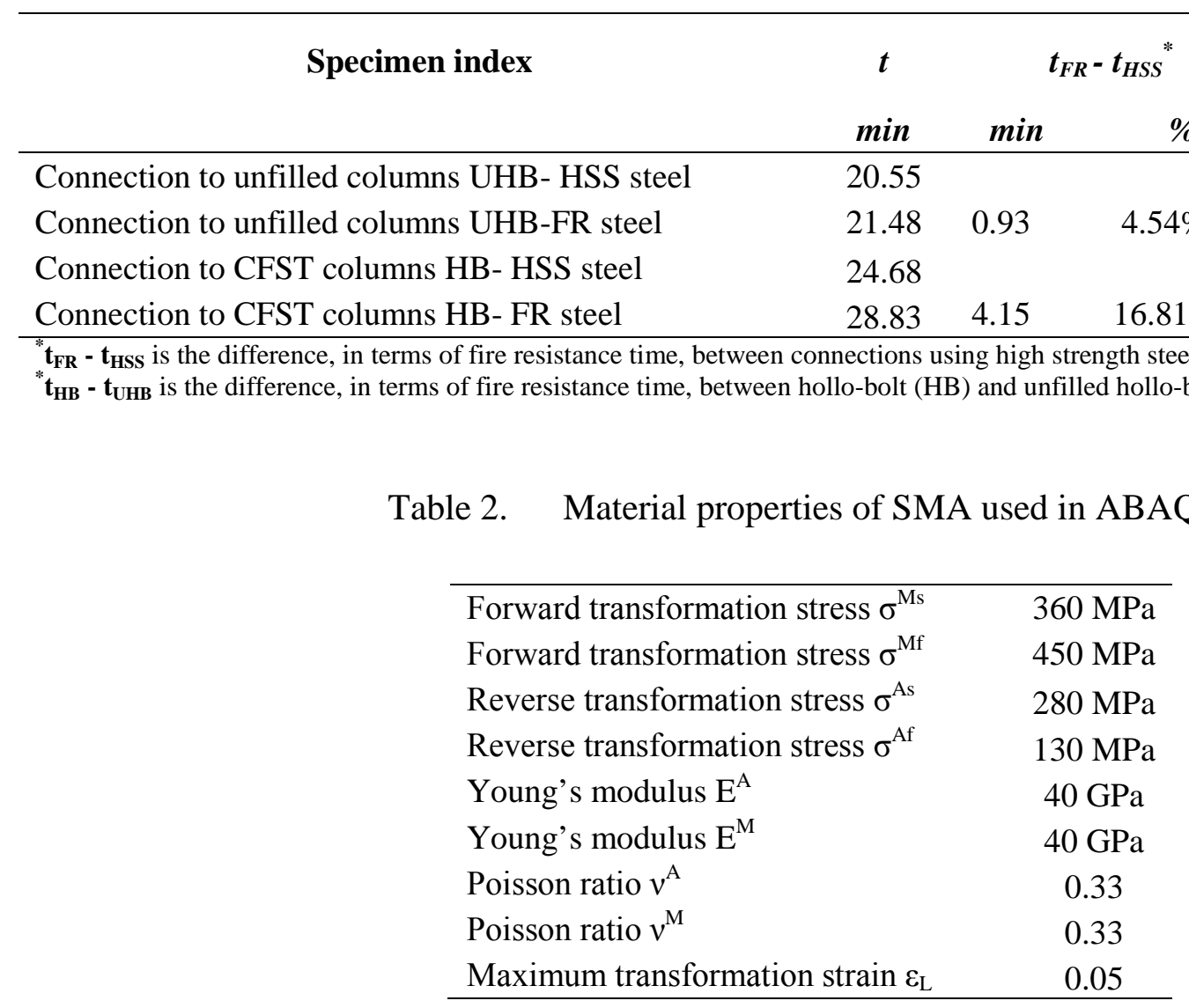




\section{LIST OF FIGURE CAPTIONS}

Fig. 1. Reduction of yield strength with temperature, for different steel grades.

Fig. 2. Comparison of the loss of strength with temperature of FR steels against general steels. [21], [22]

Fig. 3. Reduction factors from Eurocode 3 Part 1.2 Annex D [41] and for FR steel bolts from Sakumoto et al. [26]

Fig. 4. Different cross-section configurations studied: a) circular hollow section; b) double tube; c) double skin.

Fig. 5. Evolution of the axial displacement at the top end of the column, for the different cross-section configurations studied: a) circular hollow section; b) double skin; c) double tube.

Fig. 6. Axial displacement versus time curves, for different configurations tested at elevated temperatures. [8]

Fig. 7. Load versus axial displacement curves at room temperature, for the double tube specimen using different steel grades.

Fig. 8. Evolution of the axial displacement at the top end of the column, for the double tube specimen using different steel grades.

Fig. 9. Evolution of the axial displacement at the top end of the column, for the double tube specimen using fire resistant steels.

Fig. 10. Double-tube fire response using geopolymer concrete with lower conductivity.

Fig. 11. CHS fire response using geopolymer concrete and fire resistance steel.

Fig. 12. Connection of a single blind-bolt [8]

Fig. 13. Blind-bolts: Hollo-bolt [39]

Fig. 14. Numerical model of the single blind-bolted connection at room temperature [8]

Fig. 15. Cyclic loading protocol for the analysis of SMAs in blind-bolted connections [27].

Fig. 16. Stress-strain law for SMAs.

Fig. 17. Stress-strain response for blind-bolted connections to a) hollow steel section columns (Unfilled Hollo-Bolt connection. UHB); b) CFST columns (Hollo-Bolt connection. HB)

Fig. 18. Stress and plastic strain distribution in SMA and HSS bolts in connections to Hollow section columns at the end of the loading cycle.

Fig. 19. Stress and plastic straind distribution in SMA and HSS bolts in connections to CFST columns at the end of the loading cycle. 


\section{LIST OF TABLE CAPTIONS}

Table 1_Effect of using FR steel bolts on the fire resistance time of blind-bolted connections in comparison with high strength steel HSS bolts.

Table 2 Material properties of SMA used in ABAQUS. 